\title{
The Cadiz Contourite Channel: Sandy contourites, bedforms and dynamic current interaction
}

\author{
D.A.V. Stow ${ }^{\text {a }}$, F.J. Hernández-Molina ${ }^{\text {b,* }}$, E. Llave $^{\text {c }}$, M. Bruno $^{\text {d }}$, M. García ${ }^{\text {e }}$, V. Díaz del Rio ${ }^{\text {f }}$, \\ L. Somoza ${ }^{c}$, R.E. Brackenridge ${ }^{a}$ \\ a Institute of Petroleum Engineering, Heriot Watt University, Edinburgh EH14 4AS, UK \\ ${ }^{b}$ Department of Earth Sciences, Royal Holloway University of London, Egham, Surrey TW20 OEX, UK \\ ' Instituto Geológico y Minero de España, Ríos Rosas, 23, 28003 Madrid, Spain \\ d Dpto. Física Aplicada, Facultad de Ciencias del Mar, University of Cádiz, Puerto Real, Cádiz, Spain \\ e Instituto Andaluz de Ciencias de la Tierra, CSIC-Universidad de Granada, Av de las Palmeras 4, 18200 Armilla, Granada, Spain \\ ${ }^{\mathrm{f}}$ Instituto Español de Oceanografí, C/Puerto Pesquero s/n, 29640 Fuengirola, Spain
}

\section{A R T I C L E I N F O}

\section{Article history:}

Received 17 December 2010

Received in revised form 28 May 2013

Accepted 19 June 2013

Available online 26 June 2013

Communicated by D.J.W. Piper

\section{Keywords:}

Gulf of Cadiz

bottom currents

contourite channel

sandy contourites

internal tides/waves

\begin{abstract}
A B S T R A C T
The Cadiz Contourite Channel is the largest and most prominent contourite channel in the middle slope of the Gulf of Cadiz, and is known to channelise the southern branch of the Lower Core of Mediterranean Outflow Water (MOW) as it flows westwards from the Gibraltar Gateway. The channel lies in water depth between 650 and $1500 \mathrm{~m}$, is $150 \mathrm{~km}$ long, 2-12 km wide, up to $120 \mathrm{~m}$ deep, and broadly s-shaped in plan view. It has several associated subparallel marginal channels and shorter spillover channel segments. Its geometry is controlled by the interaction of a strong bottom current with the seafloor morphology, affected by neotectonic deformation and diapiric intrusion. Bottom photographs and dredge hauls reveal a channel floor shaped by high-energy flow, in places with bare rock, boulders and gravel, and elsewhere covered with sandy contourites. The rocky substrate and derived clasts are formed of authigenic iron-rich carbonates, testifying the high degree of fluid escape from adjacent diapiric ridges and mud volcanoes. The sandy substrate shows a wide range of current-induced bedforms including small, straight-crested ripples, large sinuous sand waves and dunes (wavelength 3.5-5 m, height 0.3-0.9 m), weak surface lineation on sands, and aligned gravel stringers and deep erosive scours around large boulders. Bedform orientation indicates flows directed to the south/south-west (main channel) and west (spillover channel), which can be related to MOW bottom currents, and current velocities that vary between about 0.2 and $0.8 \mathrm{~m} \mathrm{~s}^{-1}$, even in the same channel location. However, current vane orientation was clearly responding, at least in part, to tidal effects and periodicity in the Gulf of Cadiz at the time the photographs were taken. Maximum current velocities are achieved by a combination of barotropic and internal tides (probably generated at the continental slope) that reinforce the normal MOW flow. In addition, meteorologically-induced internal waves with periods shorter than tidal ones may exert an even greater influence on current intensity, especially when they occur at times of sudden changes of meteorological forcing. This effect further influences MOW variability. In all cases, the funnelling effect of the Cadiz Channel amplifies tidal or meteorologically-induced bottom currents.
\end{abstract}

(C) 2013 Elsevier B.V. All rights reserved.

\section{Introduction}

\subsection{Geological-oceanographic setting}

The Gulf of Cadiz straddles the diffuse boundary between the Eurasian and African plates, immediately west of the Straits of Gibraltar. Tectonic adjustments along this boundary led to opening of the Gibraltar oceanic gateway at the end of the Miocene, around 5.3 Ma

\footnotetext{
* Corresponding author.

E-mail addresses: dorrik.stow@pet.hw.ac.uk (D.A.V. Stow), fjhernan@uvigo.es (F.J. Hernández-Molina).
}

(Maldonado et al., 1999; Gràcia et al., 2003). Continued neotectonic activity in the region is expressed by the occurrence of mud diapirs and diapiric ridges (Diaz-del-Río et al., 2003; Somoza et al., 2003; Fernández-Puga et al., 2007; Gonzalez et al., 2007; Martin-Puertas et al., 2007; Zitellini et al., 2009). Where mud diapirs break through the seafloor they are known as mud volcanoes, and are commonly associated with gas escape. Tectonic setting and activity have been key long-term factors influencing seafloor morphological changes, which have in turn exerted strong control on the downslope and alongslope processes that have shaped the margin.

The present-day circulation pattern in the region is dominated by exchange between the Mediterranean Sea and the Atlantic Ocean of 
water masses through the Straits of Gibraltar (Fig. 1). This exchange is driven by the near-bottom flow of highly saline and warm Mediterranean Outflow Water (MOW) and the turbulent flow of less saline, cool-water mass of the Atlantic Inflow Water at the surface. The MOW forms a strong bottom current flowing towards the $\mathrm{W}$ and NW above North Atlantic Deep Water (Madelain, 1970; Melières, 1974; Zenk, 1975; Thorpe, 1976; Ambar and Howe, 1979; Zenk and Armi, 1990). After passing the Gibraltar seamount, the MOW forms a turbulent overflow only some 150 to $200 \mathrm{~m}$ wide and reaches velocities in excess of $2.7 \mathrm{~m} \mathrm{~s}^{-1}$. It then spreads westward into the Gulf of Cadiz, veering north-westward due to the Coriolis force, and progressively descends until the middle continental slope driven by gravity due to its excess density, eventually losing contact with the seafloor at 1200-1400 m water depth, where it becomes neutrally buoyant (Baringer and Price, 1999). Due to interaction with the bottom topography, the MOW splits into two principal branches (Upper and Lower MOW). The upper branch follows roughly the boundary between the upper and proximal part of the middle slope along the south Iberian margin, while the lower branch further splits into three separate strands on the middle slope, in places flowing along and down segments of both contourite and turbidite channels (Hernández-Molina et al., 2006).

The interaction of MOW with the Gulf of Cadiz margin has resulted in the development of a complex Contourite Depositional System (CDS) along the middle slope Hernández-Molina et al. (2003, 2006). This CDS represents a composite of both depositional drifts and erosional features, including several prominent contourite channels. The system has been the subject of many previous studies (e.g. Melières, 1974; Gonthier et al., 1984; Faugères et al., 1985; Stow et al., 1986, 2002b; Nelson et al., 1993, 1999; Schönfeld and Zahn, 2000; Weaver et al., 2000; Llave et al., 2001, 2004, 2006, 2007a, 2011; Mulder et al., 2002, 2003, 2006; Habgood et al., 2003; Hernández-Molina et al., 2011; Stow et al., 2011a; Roque et al., 2012). It can be divided into five major morphosedimentary sectors: 1) proximal scours and ribbons; 2) overflow sedimentary lobes; 3) channels and ridges; 4) contourite depositional sector; and 5) submarine canyons. These different sectors are clearly related to the progressive deceleration of the MOW away from the Gibraltar Gateway, frictional resistance of the seafloor, interaction with topography of the margin, and to Coriolis force (Hernández-Molina et al., 2006; Llave et al., 2007a; García et al., 2009).

This paper is principally concerned with the channels and ridges sector, which is located in the central area of the middle slope between the cities of Cadiz and Faro, lying at a water depth of between 800 and $1600 \mathrm{~m}$ (Fig. 2A). It was first studied by Nelson et al. (1993, 1999) and Baraza et al. (1999) who considered it as the "Ridge and Valley Province", but it has been described in detail more recently by several authors (García, 2002; Mulder et al., 2002, 2003; Habgood et al., 2003; Hernández-Molina et al., 2003, 2006; Llave, 2003; Hanquiez et al., 2007; Llave et al., 2007a,b; García et al., 2009). According to these authors, the principal morphological elements of the channel and ridge sector of the Cadiz margin are due to a combination of the

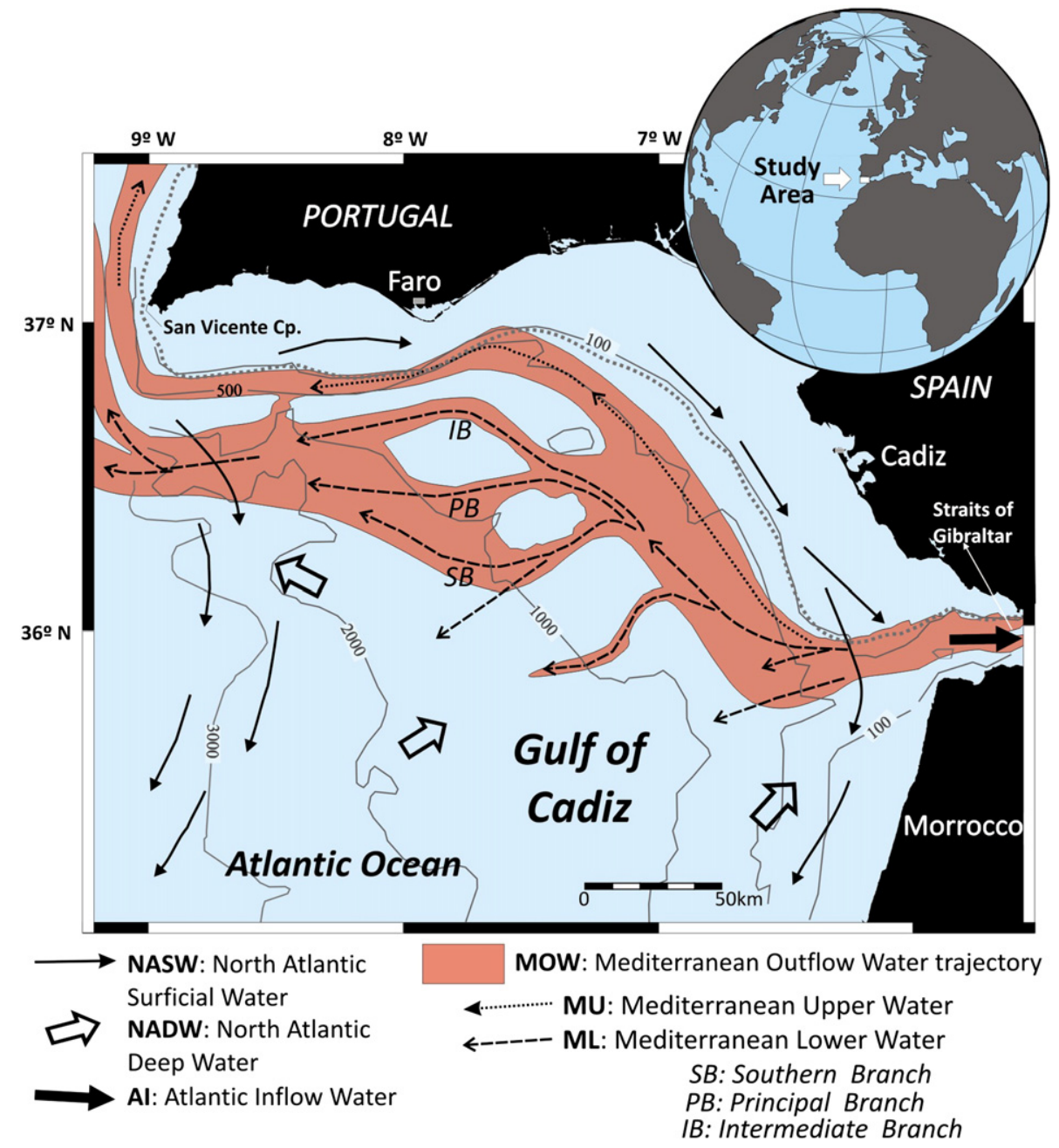

Fig. 1. Location sketch with main water-mass circulation along the margin (from Hernandez-Molina et al. 2003; Llave et al., 2011). 


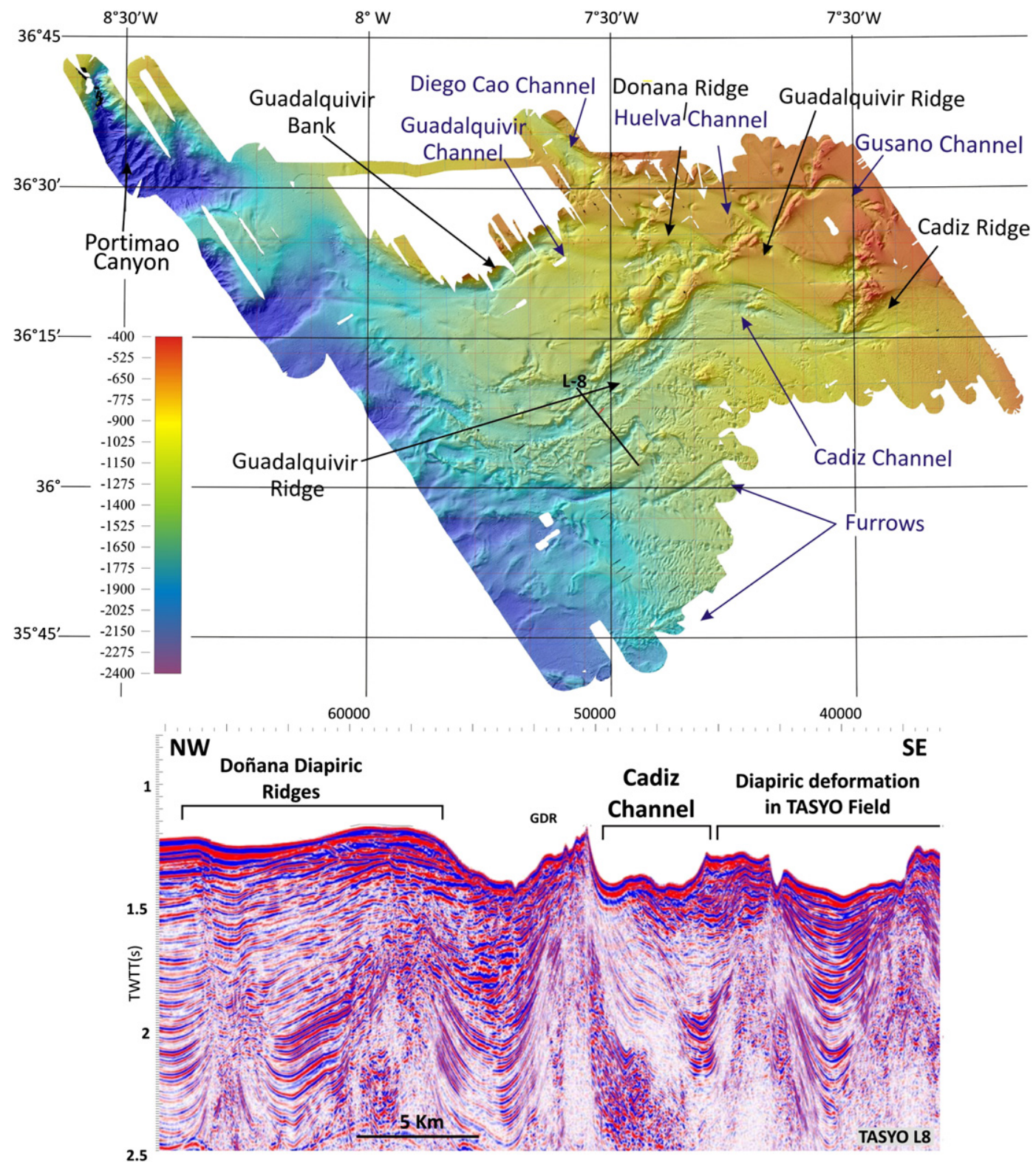

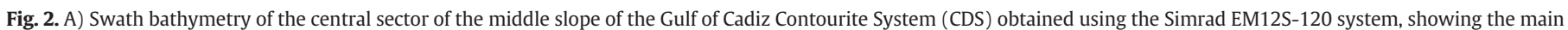

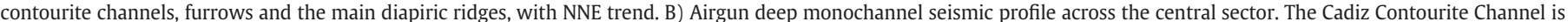
shown in A and B.

strongly erosive action of bottom currents, as they descend the continental slope, and neotectonic activity. Up to nine separate contourite channels have been identified in this sector by García et al. (2009), with five larger ones known as the Cadiz, Guadalquivir, Huelva, Diego Cao and Gusano channels (Fig. 2).

\subsection{Aims and significance}

The Cadiz Contourite Channel is the largest and best studied erosional feature of its type in the world. It shows some similarities with other deepwater channels, such as those formed by turbidity currents, but has a different origin as it is floored by contourite sands rather than turbidites. It is therefore scientifically very significant for understanding the origin of different deep sea channel types, as well as for its potential to represent a unique modern analogue of a sand-filled contourite channel for the petroleum industry. In this paper, therefore, we: (1) synthesise data on the morphology and sediment distribution within the Cadiz Contourite Channel; (2) present new photographic data on bedforms, sediment types and current flow from the main channel and adjacent channel segments; (3) consider these data, together with previously published work, in terms of bottom current velocity and its variability; and (4) discuss evidence for the influence of other oceanographic controls on bottom current velocity and resultant deposition, including internal tides and internal waves.

\section{Methods and track location}

Examination of bottom photographs is one of the principal methods by which we can determine the nature of processes operating at the present day in deep water environments. Despite much intensive research in the Gulf of Cadiz, relatively few studies present some scattered documentation of its seafloor characteristics through photographic evidence (Melières et al., 1970; Faugères et al., 1985; Stow et al., 2002a,b; Hernández-Molina et al., 2006; González et al., 2007; León et al., 2010; Maestro et al., 2011).

For this study we have examined over 3000 submarine photographs taken with a BENTHOS-372 camera, using Ecktacrome (125 ASA) and 

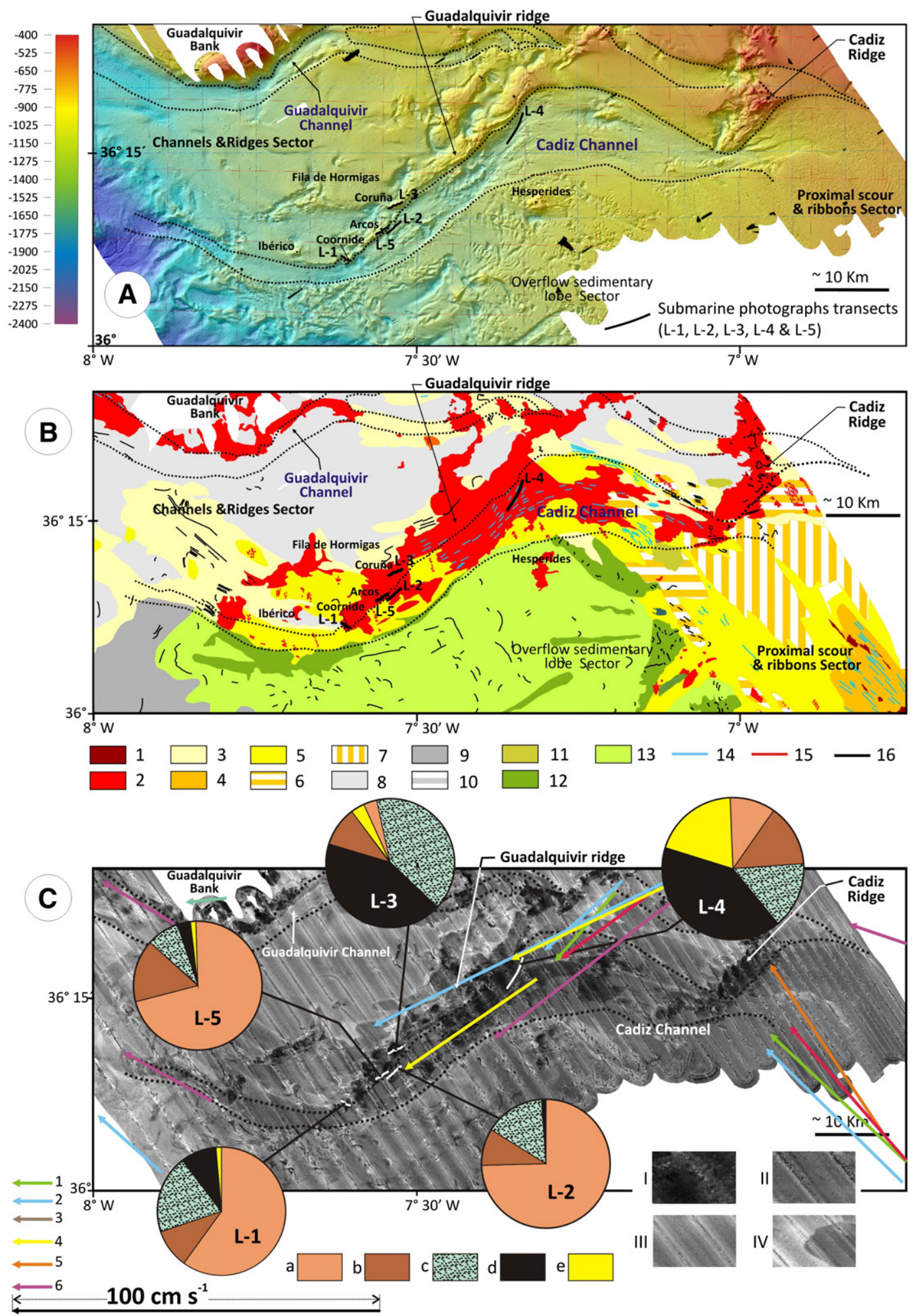

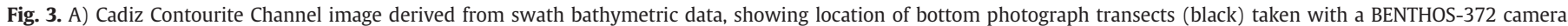

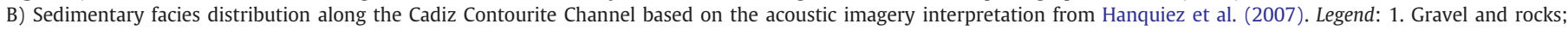

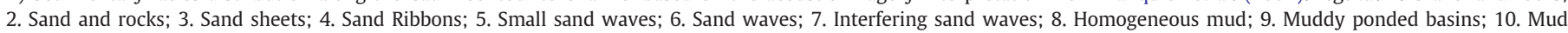

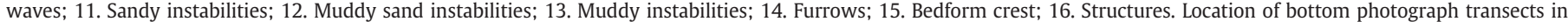

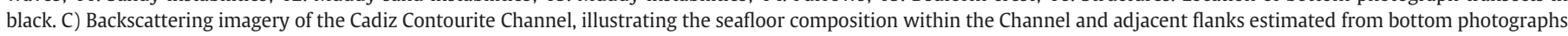

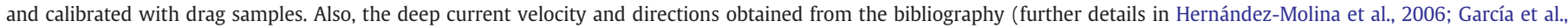

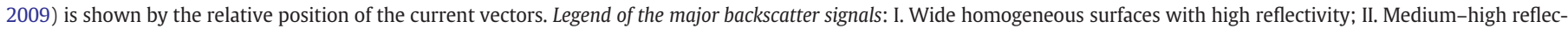

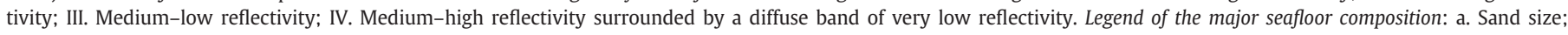
b. Pebble-small cobble size; c. Large cobble and boulder size; d. Bedrock; and e. Living organisms on rock substrate. Location of bottom photograph transects in white.

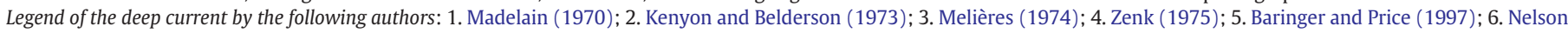
et al. (1999). 
Kodak Tri-X film, during the ANASTASYA-2001/09 cruise onboard the RV Cornide de Saavedra (Instituto Español de Oceanografia, IEO). The camera was mounted on an open box-work frame together with a downward-facing pinger, and towed 2-3 m above seafloor. Five transects (L1 to L5) were completed (Fig. 3A), two from mud volcanoes along the Guadalquivir Diapiric Ridge (L1 and L3), and three from the Cadiz Contourite Channel (L2, L4 and L5). Transect L1 crossed the flank of the Cornide mud volcano and part of a secondary contourite channel lying sub-parallel to the main channel. These photographic transects are located on the swath bathymetric map (Fig. 3A), which also shows the position of drag sampling tracklines.
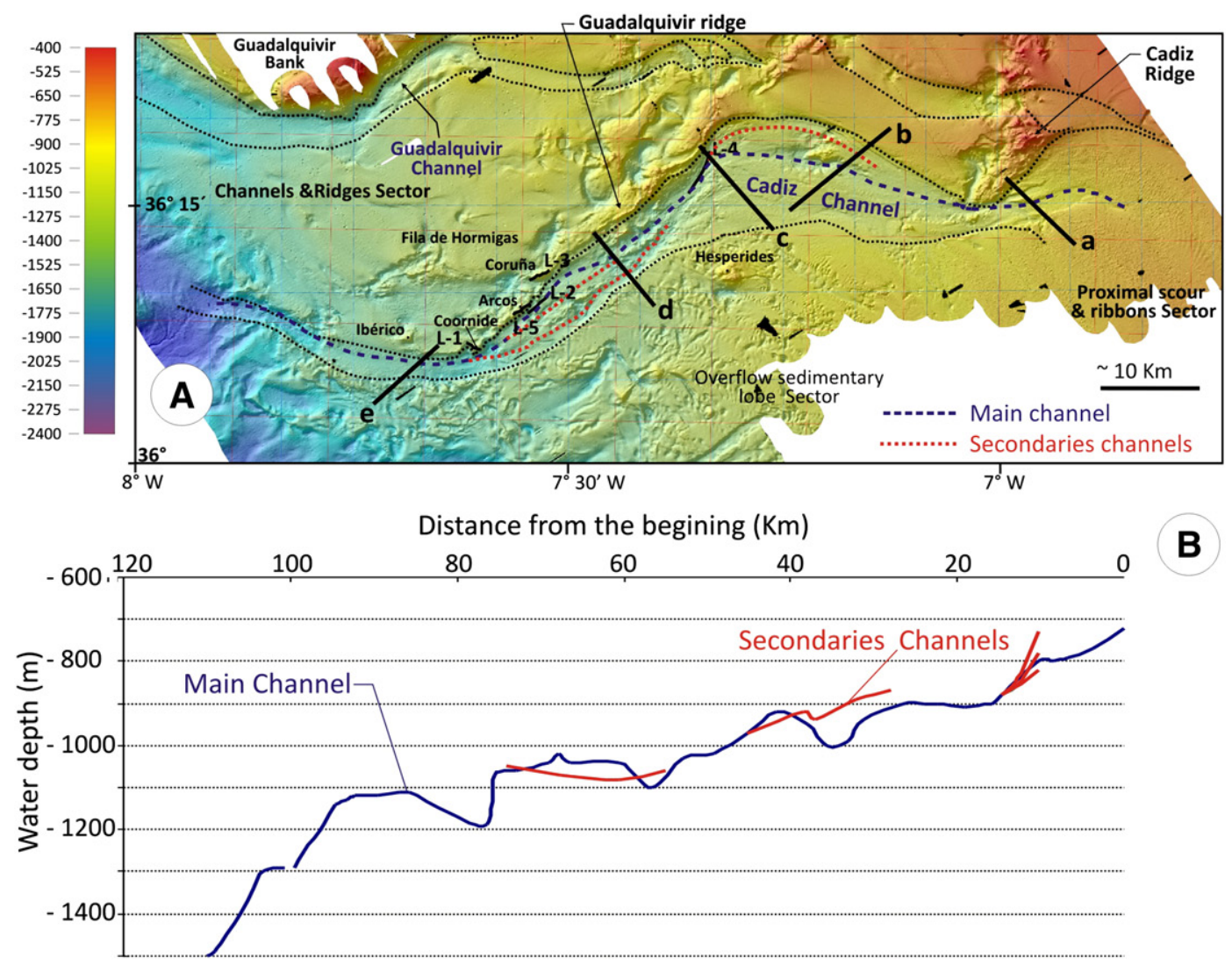

a

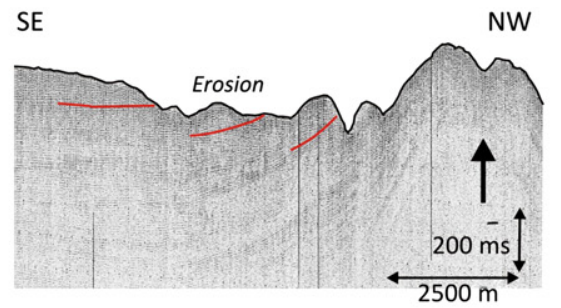

C

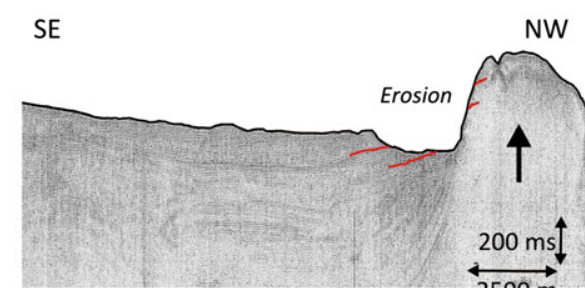

b SW

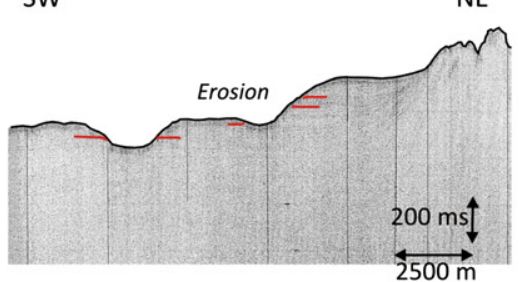

d SE

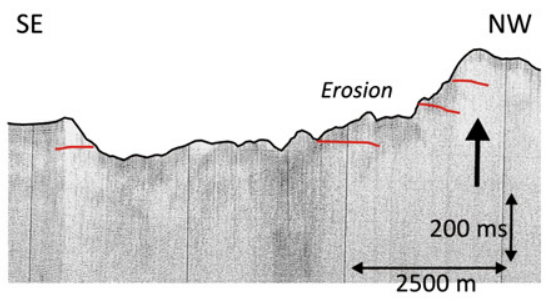

NE

C

e

SW

B 
Analysis of the photographs involved systematically recording of data on seafloor composition, estimated grain size, sedimentary bedforms (nature, scale and inferred current directions), seafloor biota, and current vane orientation. The body of the compass, which hangs from below the camera frame, is known to be $7 \mathrm{~cm}$ in diameter and the current vane $25 \mathrm{~cm}$ in length. Where visible, these have been used to calibrate the photographs as well as to obtain directional data. Several dredge hauls were also taken during the same cruise, mainly across the diapiric ridge, an isolated mud volcano and channel margins, as well as a number of short gravity cores from other mud volcanic
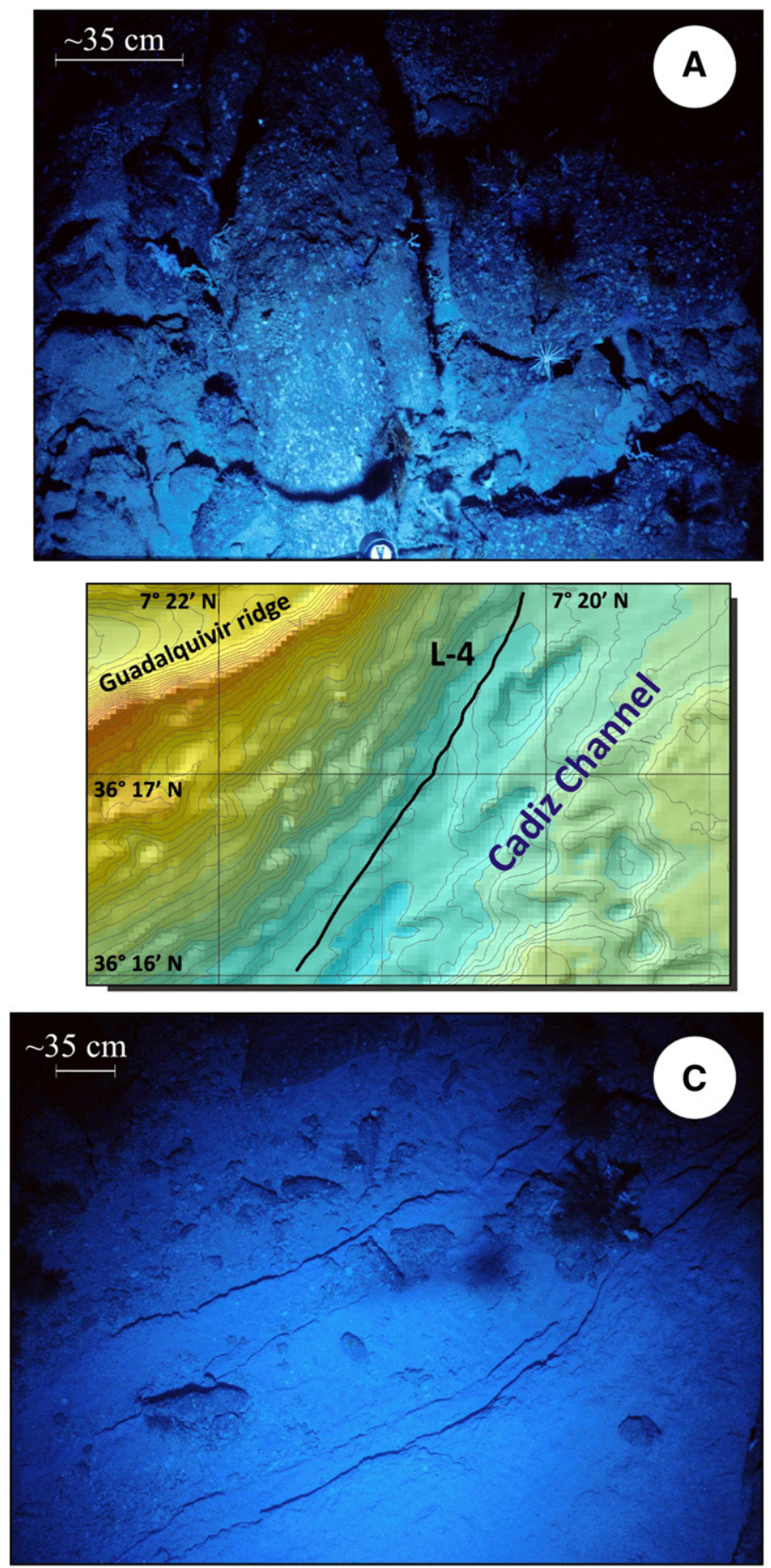

highs. Petrographic data from these sources, both textural and mineralogical, have been used to calibrate seafloor composition.

\section{Channel characteristics}

\subsection{Channel morphology}

The Cadiz Channel is the largest and the most important of the 'channels and ridges' sector (Fig. 2), having a total length of approximately $150 \mathrm{~km}$, a width of 2-12 km (average $6 \mathrm{~km}$ ), and a maximum
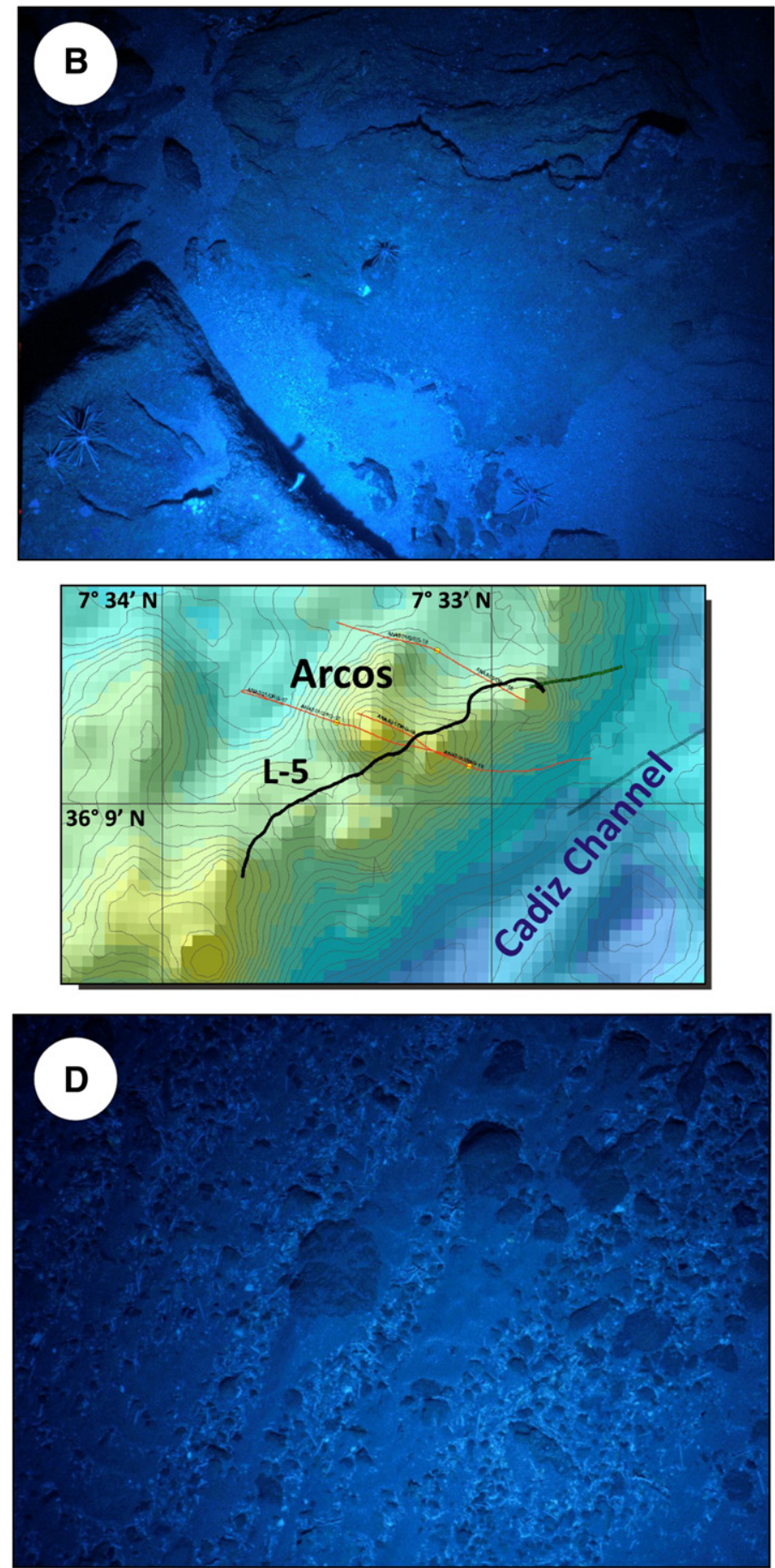

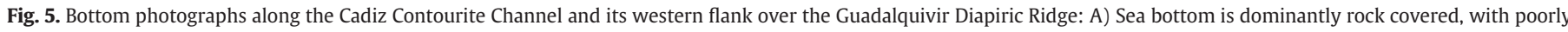

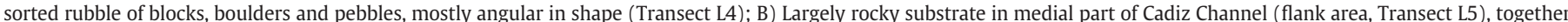

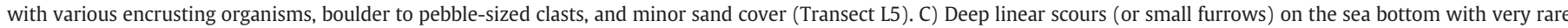

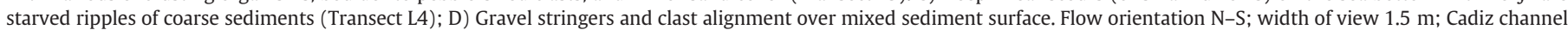
(Transect L5). Compass diameter $7 \mathrm{~cm}$; current vane $25 \mathrm{~cm}$. 
depth of incision of around $120 \mathrm{~m}$. It is broadly s-shaped in plan view with an orientation that varies from SE-NW to NE-SW (Figs. 2 and $3 \mathrm{~A}, \mathrm{~B})$. It appears to originate directly from the high energy scours and ribbons sector close to the Cadiz Diapiric Ridge at a depth of around $650 \mathrm{~m}$, and then cuts through to the Guadalquivir Diapiric Ridge, which it follows to its termination close to $1500 \mathrm{~m}$ water depth. It has a very irregular longitudinal profile, with an average gradient of $1: 200$.
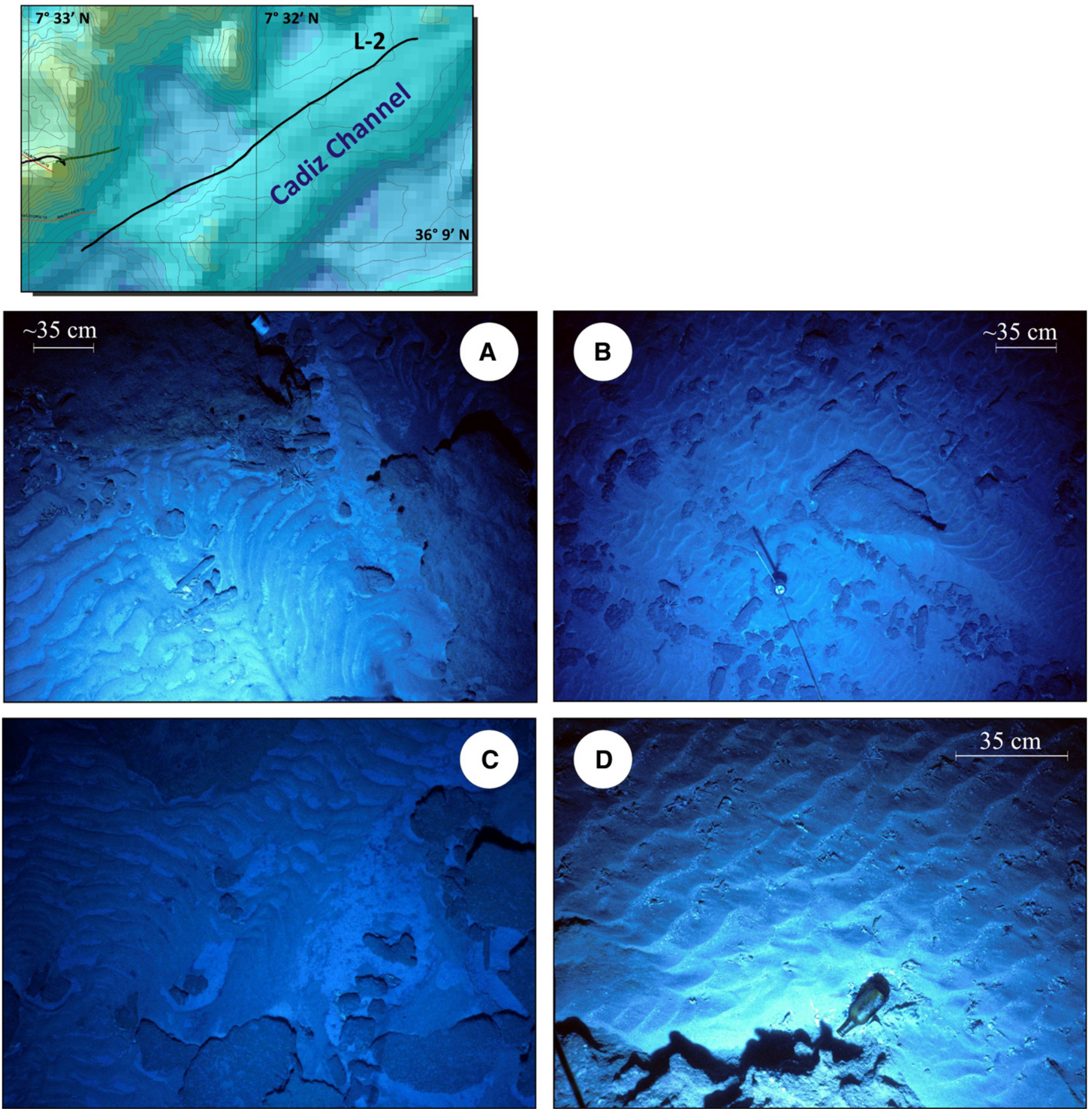

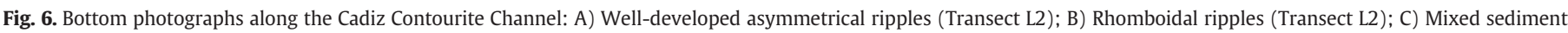

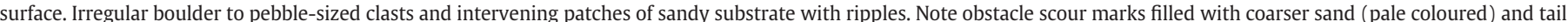

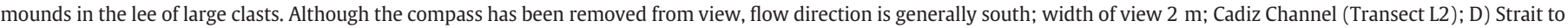

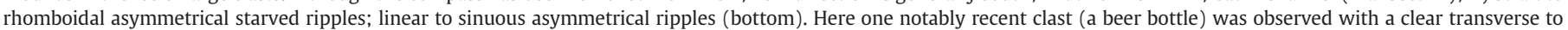
flow orientation (Transect L2). Compass diameter $7 \mathrm{~cm}$; current vane $25 \mathrm{~cm}$.
Secondary (or marginal) channels and channel segments have been identified within the Cadiz and Guadalquivir Diapiric Ridges, running in a general direction subparallel to the principal axis of the Cadiz Channel and separated from it by part of the flanking diapiric structure, at a distance between 2 and $3.5 \mathrm{~km}$ (Figs. 3A and 4). These secondary channels appear somewhat irregular and discontinuous, extending over $30-40 \mathrm{~km}$ in parts and eroding into the diapiric ridges. The principal axis of the channel has eroded a broader and 

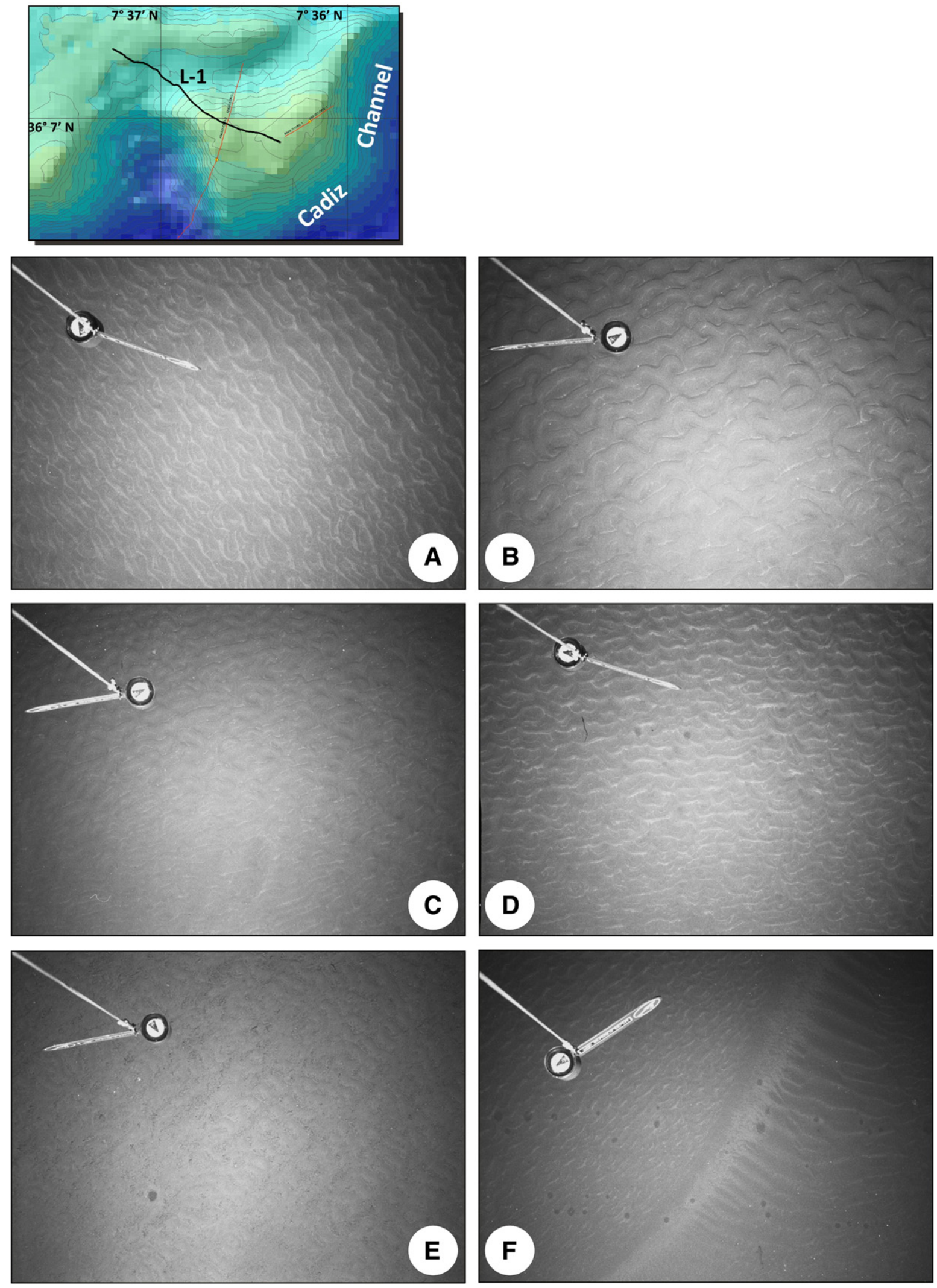

Fig. 7. Bottom photographs along the Cadiz secondary channel: A) Linear to sinuous asymmetrical ripples (sharp-crested) from the Cadiz secondary channel. Ripple orientation indicates flow towards the west, whereas the current vane shows flow direction towards south at time of photo at time of photo (Transect L1); B) Linear to sinuous asymmetrical ripples (round-crested), typical of the Cadiz secondary channel. Ripple orientation indicates flow towards the west, whereas the current vane shows flow direction towards SSW $\left(205^{\circ}\right)$ (Transect L1); C) As (B) but with rather more symmetrical primary ripples and secondary interference pattern from N-S or S-N directed flow (Transect L1); D) Interference ripple pattern with sharp-crested ripples; E) Surface lineation on fine sandy substrate showing current flow oriented E-W or W-E, whereas current vane indicates present flow towards SSE (115을 (Transect L1); F) Sinuous to crescent sand waves, observed in the Cadiz secondary channel (Transect L1). Stoss side with small regular asymmetrical ripples, lee side with linear erosional chutes, and sand wave trough region with more irregular ripple pattern. Both ripple and dune orientation indicates flow towards the west, whereas the current vane shows more southerly flow direction at time of photo. Compass diameter $7 \mathrm{~cm}$; current vane $25 \mathrm{~cm}$. 
flatter floor at greater depths than the secondary channel axes (Fig. 4). Depth differences up to $130 \mathrm{~m}$ exist between the principal and secondary channel axes (Fig. 4). In some parts there are short secondary channel segments that cross obliquely from the principal Cadiz Channel into the main subparallel secondary channel.

\subsection{Sediment nature and composition}

Semi-quantitative data collected from all bottom photographs reveals the proportion of seafloor covered by silt and sand, pebble to small cobble-sized clasts, large cobble and boulder-sized clasts, and continuous rocky substrate, part of which is covered by biogenic material (living organisms). Comparison between the different tracklines is shown in Fig. $3 \mathrm{C}$.

Only limited sediment samples have been recovered from within the channels and ridges and adjacent sectors. Two short gravity cores from the northern margin of the Cadiz Channel (elevated diapiric zone) and mud volcano regions recovered structureless, bioturbated muds, mottled silts and indistinctly laminated silt-mud facies. These are interpreted as typical fine-grained contourite facies (Fig. 13.2 in Stow and Faugères, 2008). A single gravity core from the southern overbank area somewhat more distant from the Cadiz Channel, in the overflow lobe sector, was described by Habgood (2002) and interpreted as representing muddy contourites. Sand-rich facies have been recovered from the sand sheet in the scour and ribbon sector, immediately east of proximal Cadiz Channel. The cores show both parallel and inclined lamination (large-scale cross-bedding), which we interpret as the result of sand wave migration across this sand sheet under the influence of strong bottom currents. The sands are medium to coarse-grained, moderately well sorted and with a very mixed bioclastic/siliciclastic composition. They have been interpreted as contourite sands (Fig. 13.5 in Stow and Faugères, 2008; Stow et al. 2011b).

The only sediment recovered from within the Cadiz Channel is from surface dredge hauls. In addition to a variety of shapes and sizes of iron-carbonate clasts, which are almost certainly locally derived from the authigenic iron-rich carbonates associated with the adjacent diapiric ridge, there are fine to coarse-grained sands. These have a very similar mixed bioclastic/siliciclastic composition to those from the sand sheet described above, but with the notable addition of authigenic grains of iron-rich carbonates. The siliciclastic components include dominant quartz, minor lithic fragments, altered and iron-oxide coated grains, and rare glauconite. The bioclastic debris is mostly highly fragmented, including bivalves, echinoid spines, and benthic foraminifers with pyritefilled chambers.

Photographs from the more proximal channel region (transect L4), close to the diapiric ridge, show a seafloor dominated by rocky substrate with an irregular and often fractured surface, colonised in patches by organisms (Fig. 5). In parts, there is a poorly sorted rubble of blocks, boulders and pebbles, mostly angular in shape and with a dark tarnished colour, and also fragments of paler bioclastic debris. There are isolated zones of sediment cover, in some cases with deep linear scours (Fig. 5), between the larger clasts and rocky substrate, as well as a very thin sediment coating over some clasts. Overall, there is a significant proportion of presumed living organisms: feather stars (Ceramaster placenta), echinoderms (Cidaris cidaris), and various species of hard coral (e.g. Lophelia), soft coral, sea squirts and rare crustaceans. The sea squirts occur both as single large organisms and in colonies of 30-50 clustered individuals over larger rock surfaces.

The rocky substrate and associated clasts are the dominant material recovered in dredge hauls across the adjacent diapiric ridge (Fig. 5) and observed in bottom photographs of transects L3 and L4, as well as in parts of the other transects. They mainly comprise authigenic iron-rich carbonates (Fe-dolomite, ankerite and calcite) and metal-oxide-sulphide minerals typically formed in chimneys, slabs, crusts and nodules associated with hydrocarbon-rich fluid vents in the Gulf of Cadiz on and around the Guadalquivir Diapiric Ridge (Diaz del Rio et al., 2003; Merinero et al., 2008; González et al., 2009, 2010; León et al., 2010). Some of the larger clasts recovered in dredge hauls are iron carbonate cemented breccias, most likely derived as talus from the flanks of mud diapirs and mud volcanoes with an early cementation on the seafloor.

The seafloor imaged in photographs from the more medial-distal channel region (transects L2 and L5. Figs. 5 and 6) is dominated by a sandy substrate (silts and sands), commonly with distinctive currentinduced bedforms (mostly ripples of various types). There is a smaller proportion of scattered, pebble to small cobble-sized, angular clasts, commonly arranged in linear stringers, and still less scattered boulder clasts. Solid bedrock substrate is very rarely present, but both this and the rocky clasts have the same appearance as those of Transect 4 . As a consequence of a lack of a widespread hard substrate, living organisms are also extremely rare.

Transect L1 runs from the flank of the Cornide Mud Volcano and into the axis of a short secondary channel. The flank region is dominated by large elongate clasts and boulders of iron-rich carbonates, most of which are remnants of fallen carbonate chimneys as clearly revealed by dredge hauls. The spillover channel is completely covered with a sandy substrate, showing both dune and ripple bedforms (Fig. 7). There is a notable lack of silt or clay in this or in the main channel.

\subsection{Sedimentary bedforms and gravel alignment}

A wide range of current-induced bedforms are common in photographs from the medial-distal channel location (transects L2 and L5), as well as from the secondary channel (transect L1), suggesting that they formed under the action of varying flow velocities (Figs. 5-7). The lowest energy bedforms include surface lineation, very small (1-3 cm wavelength) and small (3-4 cm wavelength) straight-crested ripples. Moderate energy bedforms are the most commonly observed, ranging from straight to sinuous-crested ripples (wavelength $7-8 \mathrm{~cm}$ ), with distinct linguoid ripples (wavelength 7-10 cm) less common. Whereas most of the ripples appear sharp crested and markedly asymmetric in form (Fig. 6D), some areas show rounded crests and more symmetrical form (Fig. 6A), and others have distinctive patterns of interference ripples (Fig. 7A, B).

The highest energy bedforms observed are large sand waves, with wavelengths of around 3.5-5 $\mathrm{m}$ and trough to crest heights of $0.3-$ $0.9 \mathrm{~m}$ (although the wave height is more difficult to ascertain precisely from bottom photographs). These sand waves are particularly evident in the secondary channel (transect L1, over 30 sand waves measured), where they generally show superimposed smaller-scale ripples (Fig. 7F). The ripple trains have a regular migration pattern up the stoss side and a more chaotic organisation in the trough region. The lip of the sand wave crest is smooth, while the lee face is either smooth or with a regularly-spaced ridge and groove structure. Both straight crested and sinuous to lunate wave forms are apparent. Within the main Cadiz Channel, only two large sand waves have been partially captured in bottom photographs. In each case, the lee face is smooth and the stoss side partly covered with small-scale ripples.

Where the substrate is coarser grained, alignment of gravel clasts is also commonly observed (Figs. 5D, 6B). Finer gravel (and up to small cobble size) occurs in linear stringers, from $50 \mathrm{~cm}$ to at least $2 \mathrm{~m}$ in length (i.e. across the full frame of view). Size sorting in these stringers is extremely poor, and the orientation of elongate clasts is mostly transverse to flow direction. However, parallel-orientated elongate clasts are also noted in places. Stringers mainly occur approximately perpendicular to ripple crestlines, where these are visible in the same frame. One notably recent clast - a beer bottle - was observed with a clear transverse to flow orientation (Fig. 6D). 


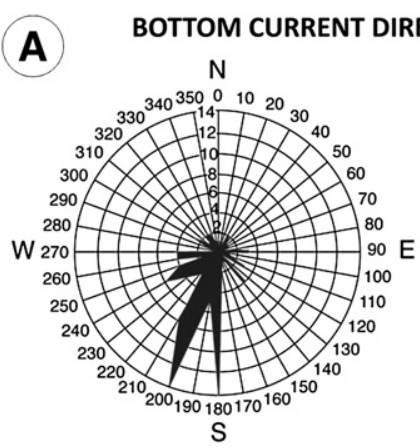

TRANSECT 2,5

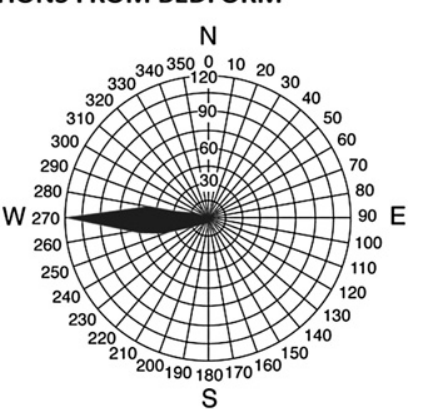

TRANSECT 1

BOTTOM CURRENT DIRECTIONS FROM VANE ORIENTATION

B

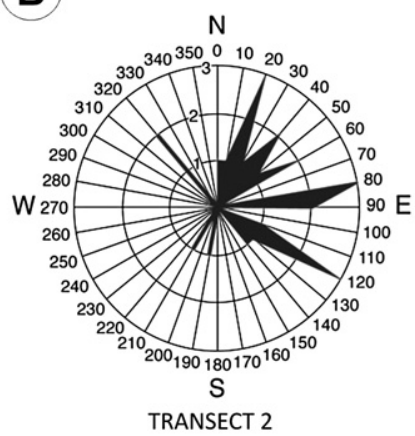

$\mathrm{N}$

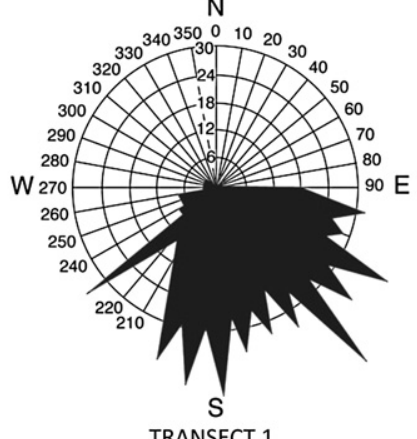

TRANSECT 1

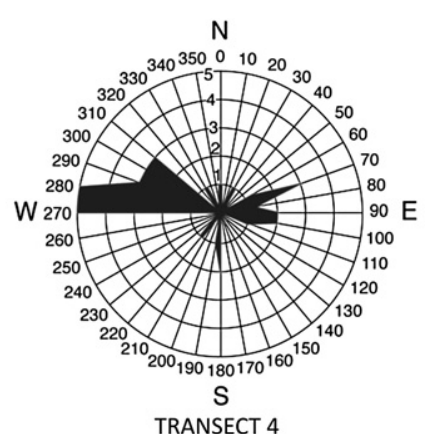

$\mathrm{N}$

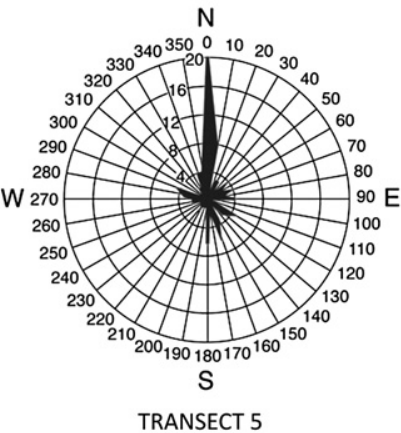

TRANSECT 5

Fig. 8. A) Bottom current directions as inferred from bedform measurement for Transects L2 and L5 (total of 105 readings); and Transect L1 (total of 234 readings). B) Bottom current directions during the running of each transect as inferred from current vane orientation.

Obstacle scour and tail marks are visible in some photographs around the larger boulders, and the tails may extend into gravel stringers. Somewhat irregular, linear furrows (approximately $5 \mathrm{~cm}$ wide) are visible in very few frames from the proximal channel location only (Transect L4, Fig. 5).

\subsection{Directional data from bedforms}

Bottom current flow direction can be determined from the variety of bedforms and clast alignments described above, and this can be given a specific orientation when the suspended compass is in view in the same frame. The ripples and sand waves are, in most cases, clearly asymmetric and so formed under unidirectional flow - they yield a unique flow direction. Gravel stringers, where not associated with ripples and not formed in the lee of boulders, cannot give a unique direction. The same applies to surface lineation on sandy substrates. Data from over 100 measurements made on photographs from transects L2 and L5 (Cadiz Channel) and from over 230 measurements from transect L1 (secondary channel) are show in Fig. 8.

For the main Cadiz Channel, there is a dominant preferred flow direction towards the SW quadrant, with some scatter observed from due south to due west (Fig. 8A). At least some of this variation is attributable to the observed curved patterns of ripple crest orientation around large obstacles (boulders or rocky substrate) on the seafloor; some may be due to current interaction with local seafloor topography. Only some $15 \%$ of readings indicate significantly different directions. Clearly, this flow direction would have been anticipated on the basis of the SW orientation of the Cadiz Channel and the well documented flow of the Southern Branch of the Lower MOW water mass along this segment of channel.

For the secondary channel segment, there is an even tighter spread of measurements around a preferred flow direction due west, with close correspondence between ripple and sand wave orientation. Surface lineations also line up with an east-west trend. The locally more chaotic ripple orientations, which are noted immediately in front of the lee face of sand waves, have not been included on Fig. 8A.

Interference ripple patterns are not uncommon in parts of the secondary channel (transect L1), but much more rarely observed in photographs from the main channel (transects 2 and 5). In each case, these show one principal orientation formed by flow towards the $\mathrm{W}$ or SW, and one secondary pattern indicating flow more or less at right angles to this direction or partly reversed. However, the nature of the flow or flow direction involved in creating such interference patterns cannot be ascertained from the photographic records.

\section{Bottom current and tidal data}

\subsection{Current vane measurements}

With such clear directional data for the inferred depositing current, as derived from bedform orientation (above), the independent measurement of extant current flow directions (i.e. those pertaining at the time of the photograph), based on current vane orientations, is somewhat surprising. The extant current directions obtained from 126 different photographs in the main channel (transects L2, L4 and L5), and over 500 measurements in the secondary channel (transect L1) are very different and varied (Fig. 8B). Very little unequivocal data was obtained from transect L3, mainly due to lack of compass visibility or to compass grounding. During the acquisition of transect 4, current direction varied between generally westward and eastward, with some additional scatter. During the acquisition of transect 5 , they were dominated by a northward direction, also with minor scatter. Finally, during transect 2 there was considerable variation in current direction with no single dominant sense. In the main channel, therefore, the indications were of a relatively weak and variable current, although somewhat stronger and more unidirectional during the acquisition of transect 5. For neither transect 2 nor 5 were the flow directions derived from the current vane coincident with flow directions inferred from channel floor bedforms. Nor were they uniformly directed to the west as might have been expected from what we know of the generally westward directed MOW currents.

The large number of measurements from transect 1 on the flank of Cornide Mud Volcano and in the secondary channel show preferred flow directed towards the southeastern quadrant, but with marked scatter from due east to southwest. Here too, the indications are for a somewhat weak and variable current with a significantly different flow orientation, both from that derived from bedform observation in the channel and from that expected from previous and extensive MOW measurements.

It is important to note that many of the current vane measurements are entirely opposed to those derived from bedform analysis (Fig. 8). This is clear evidence of reverse-flow currents. 

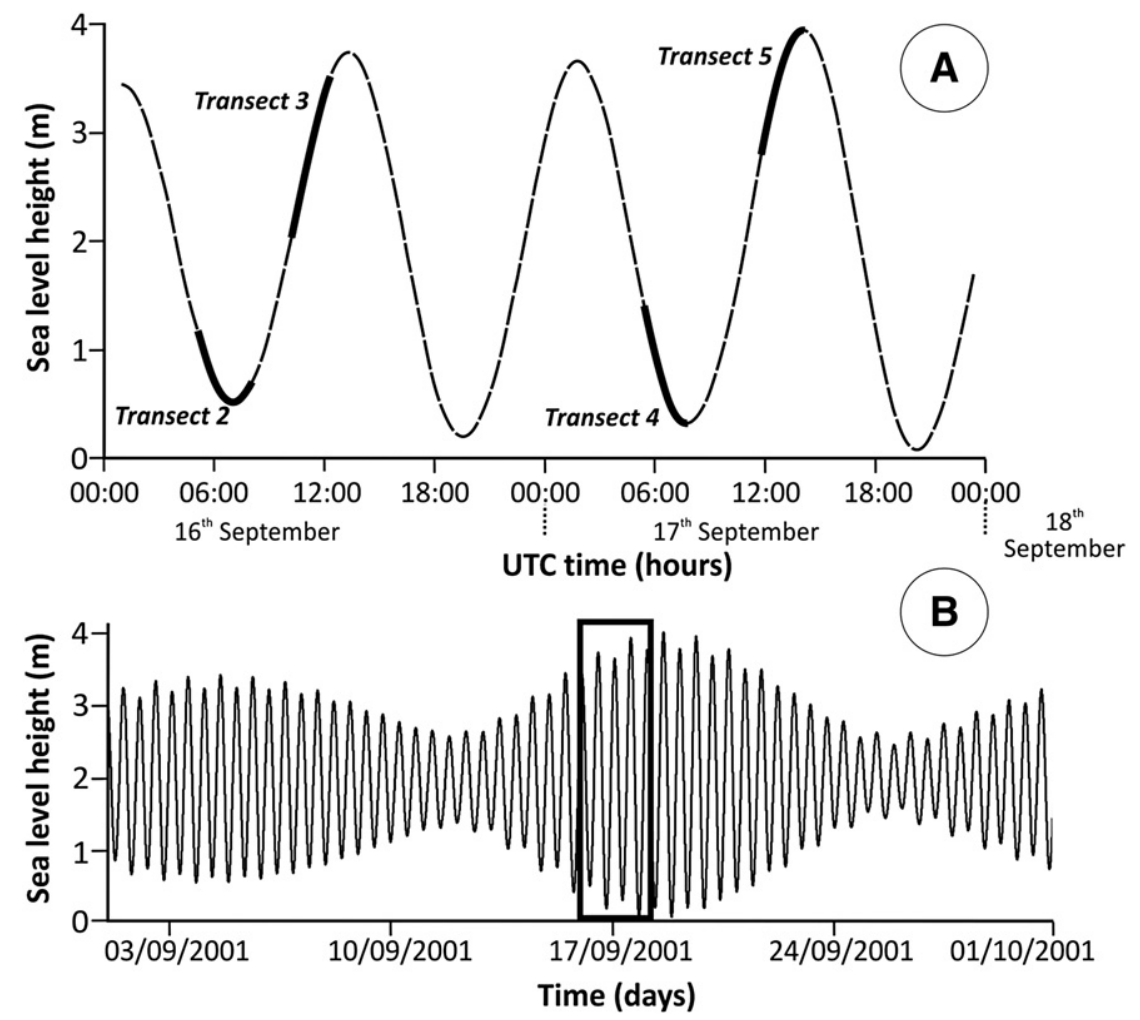

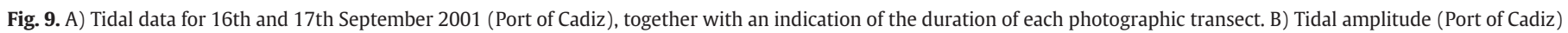
through the month of September 2001. The rectangle indicates the approximate total period of photographic transects.

\subsection{Tidal data}

Because of the apparent discrepancy of current vane orientation with both bottom bedform indications and known MOW flow direction, we consider here the relevant information on tides in the Gulf of Cadiz at the times the photographic transects were acquired. Data from the Admiralty Tide Tables (2001) for the Port of Cadiz on 16th and 17th September 2001 is shown in Fig. 9A, together with the duration of photographic transects 2, 3, 4 and 5 (adjusted for GMT timings recorded at sea). Full moon fell on 17th September with the subsequent spring tide on 18th September, so that tidal influence would have been close to its maximum around these dates.

Bottom photographs on transects 2 and 4 were taken approximately $24 \mathrm{~h}$ apart around low water on 16th and 17th respectively, and both show variable current vane orientations. Transect 5 photographs, showing dominant northerly directed currents from current vane orientation, were taken some $6 \mathrm{~h}$ after Transect 4 , on the afternoon of 17th September, near high tide. Although data from transect 3 is very limited, as explained previously, this also shows more or less consistent northerly directed flow.

Transect L1 was carried out in the morning of 8th September, some 9 days prior to transect 5 and hence to high spring tide on 17th September. Photographs were taken at and just after high tide. Measurements during this transect showed a weaker current regime and a more or less reverse direction from that during transect L5. It would seem, therefore, that the state of the tidal cycle, spring/neap tides, is linked to a greater/smaller intensity of the bottom currents in the observation places. However, there are also fluctuations in the currents with periods much shorter than the basic tidal ones, which appear not to be related to tides. This is evidenced most clearly by the reversal of current velocity during transect L4 with a time interval of approximately $2 \mathrm{~h}$.

\section{Discussion}

\subsection{Cadiz Contourite Channel}

The Cadiz Contourite Channel is known to capture the southern branch of the Lower MOW Water Mass as it flows westwards along the south Iberian margin. A compilation of multiple datasets indicates a morphosedimentary framework that reflects progressive decrease in the strength and influence of MOW, from a maximum as it leaves the Gibraltar Gateway to a much more moderate level as it rounds the Iberian margin south of Cape St. Vincent (e.g., HernándezMolina et al., 2006, 2011; García et al., 2009). The broadly s-shaped plan view of the Cadiz Channel is determined by interaction of this bottom current with the Cadiz and Guadalquivir Diapiric Ridges. Recent collation of more high resolution acoustic imagery over the southeastern sector of the Iberian margin (Habgood, 2002; Hanquiez, 2006; García et al., 2009) shows clear evidence of high-energy currents and active diapirism within and adjacent to the Cadiz Channel.

West of the Gibraltar Gateway, a scoured rocky substrate gives way to gravel stringers and sand sheets cut through by deep erosive furrows within the channels and ridges sector. The Cadiz Channel evolves from the western end of this sector and is also floored by rock, boulders, gravel and sand. The rocky substrate and derived boulders and gravel are formed of authigenic iron-rich carbonates as a direct result of fluid emanations from the diapiric ridges and isolated mud volcanoes, and subsequent break-up and down-flank collapse into the channel. Although this process would have also delivered considerable volume of mud to the channel, almost all vestiges of silt and clay have been swept away. The sheer abundance of this iron-rich carbonate material, as demonstrated by the new photographic evidence presented here, indicates the high degree of fluid escape in the area, linked to an active neotectonic system (Diaz del 


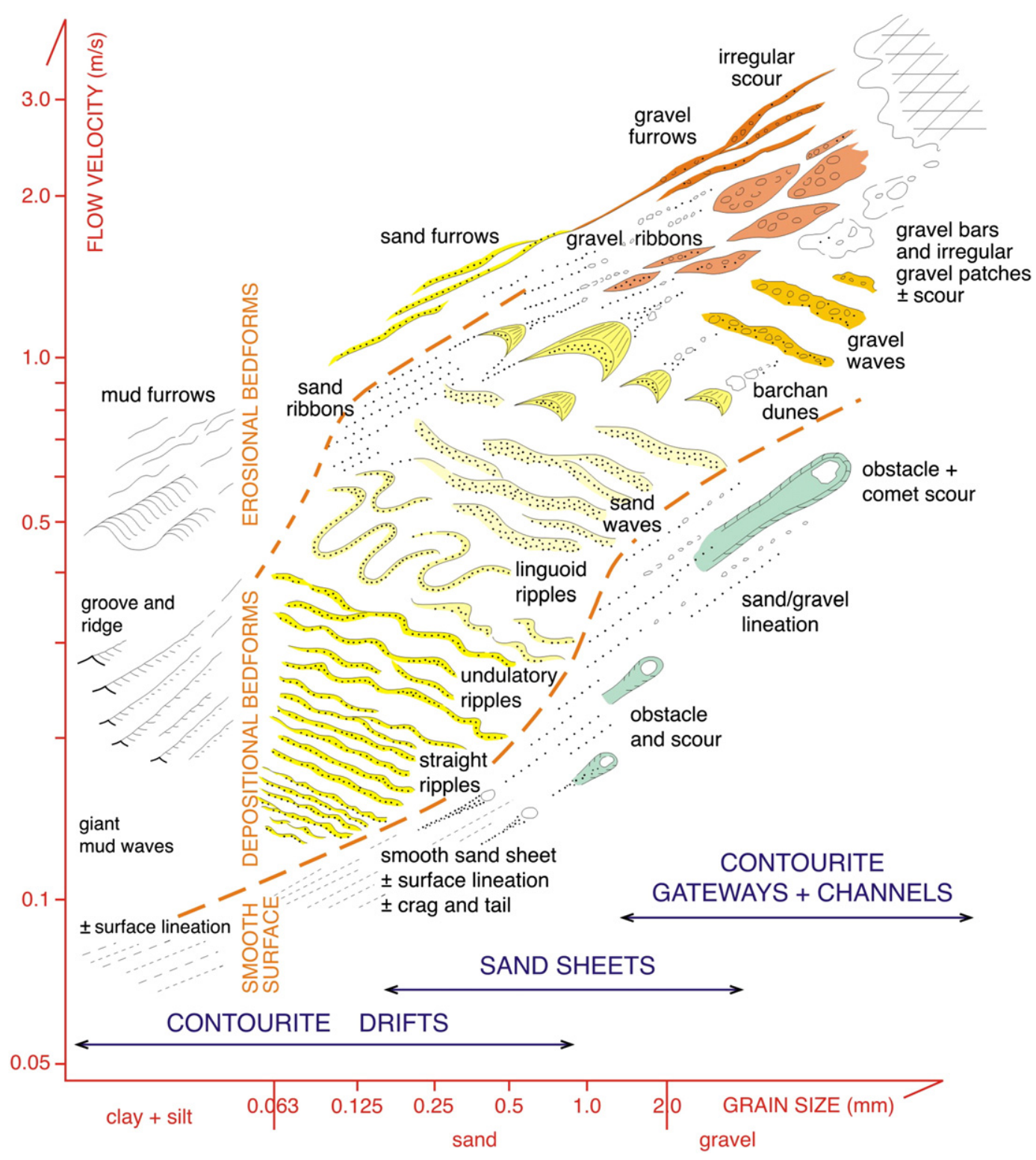

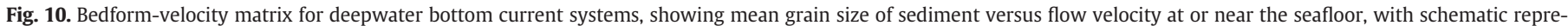
sentation of the bedforms present under specific velocity-grain size conditions (modified and adapted from Stow et al., 2009).

Rio et al., 2003; Somoza et al., 2003; González et al., 2007, 2009, 2010; Jané, 2007; Merinero et al., 2008; León et al., 2010).

The remainder of the channel is covered by sand, of unknown thickness but certainly thick enough to form well-developed sand waves. A certain proportion of the grains (approximately 15\%) comprises abraded fragments from the fallen boulders and gravel clasts, together with broken-up bioclastic grains. The former are locally derived, whereas the latter appear to be of mixed derivation, as some are shallow-water bioclast fragments and others deeper water faunal varieties. The former tend to be more well-rounded in shape. However, the greater proportion of mineral grains must have their immediate source in the cursive further upflow. This extensive sand sheet also has a mixed source, from shelf sands along the Iberian margin and from erosion and transport through the Gibraltar Gateway. Based on the source of sands, the lack of any direct turbidity current pathway to the channel, and the many data that show strong flow of the Lower MOW to and through Cadiz Channel, there can be little doubt in interpreting the sands as contouritic.

\subsection{Bottom current velocity}

Previous efforts to determine bottom current velocity for various parts of the MOW in the Gulf of Cadiz (e.g. Madelain, 1970; Kenyon and Belderson, 1973; Ambar and Howe, 1979; Baringer and Price, 1999; Nelson et al., 1999; Criado-Aldeanueva et al., 2006; Hanquiez, 2006) have been recently synthesised by García (2002), HernándezMolina et al. (2006) and García et al. (2009). Whereas the overall velocity shows a marked decrease from $>2.7 \mathrm{~m} \mathrm{~s}^{-1}$ in the Gibraltar Gateway to around $0.1-0.15 \mathrm{~m} \mathrm{~s}^{-1}$ south of Cape St. Vincent, there is much variation even within the same morphosedimentary sector.

Estimates for the channels and ridges sector, including the Cadiz Contourite Channel, are typically in the range 0.2 to $0.8 \mathrm{~m} \mathrm{~s}^{-1}$. Values as low as $0.14 \mathrm{~m} \mathrm{~s}^{-1}$ have been reported over interchannel areas, and 0.18 to $0.36 \mathrm{~m} \mathrm{~s}^{-1}$ in the Guadalquivir Channel (Hanquiez, 2006; Hanquiez et al., 2007), whereas some studies have reported values as high as $1 \mathrm{~m} \mathrm{~s}^{-1}$ over sand waves in the Cadiz Channel (Nelson et al., 1993, 1999). Part of this variation may be due to the different 
types of data used, including spot current meter measurements, granulometric data from cores and bedforms observed with acoustic images. But these cannot explain the full picture that emerges from the latest data presented here.

Using the velocity versus bedform matrix for bottom currents, recently proposed by Stow et al. (2009), we estimate a range of current velocities mainly between 0.2 and $0.8 \mathrm{~m} \mathrm{~s}^{-1}$ (Fig. 10). The individual errors associated with these estimates are discussed in the original publication (Stow et al., 2009), but for the purposes of this discussion, the exact values are of less concern than the relative variation. In fact, these estimates agree well with previous data (above) but also, because the photographs reveal actual current bedforms, it is possible to confirm their formation under low velocity flows (around $0.2 \mathrm{~m} \mathrm{~s}^{-1}$ for small straight-crested ripples), moderate velocities (0.3-0.5 $\mathrm{m} \mathrm{s}^{-1}$ for linguoid ripples), as well as higher velocity episodes (up to at least $0.8 \mathrm{~m} \mathrm{~s}^{-1}$ for sand waves). Movement of some of the larger gravel clasts into linear trains would require velocities at the higher end of this spectrum, possibly even in excess of $0.8 \mathrm{~m} \mathrm{~s}^{-1}$, as inferred by Hernández-Molina et al. (2006), whereas evidence also exists for smooth sediment surfaces, some with lineation marks, indicating velocities of $<0.15 \mathrm{~m} \mathrm{~s}^{-1}$.

It is further significant that all of these bedforms co-exist within the same relatively small sector of the channel, and in some cases in the same field of view (e.g. where ripples are seen climbing the stoss side of a larger sandwave). There is no doubt, therefore, that bottom current velocity within the channel has varied considerably in a short space of time. Furthermore, the current vane data indicates that periodic slack water and reverse flows also occur.

\subsection{Bottom current variability}

In their insightful paper of 1973, Kenyon and Belderson recognised some of the evidence for bottom current variation in the Gulf of Cadiz and suggested that it may be due to local topographic changes and the interaction of different oceanographic processes. In fact, there are several potential influences on bottom current flow both in the Gulf of Cadiz and elsewhere in the oceans.

(1) Open ocean tides. The barotropic tidal current is that part of the current that is coupled with vertical variations of sea level produced by propagation of the tidal wave and has a constant velocity with depth. The amplitude of this current in the open ocean over the middle slope of the Cadiz margin can be inferred from data provided by the Rayo buoy (Puertos del Estado) as around $10 \mathrm{~cm} / \mathrm{s}$. This is a similar order of magnitude to that found in the middle slope of the nearby Portimao Canyon area (Bruno et al., 2006). However, it is very likely that the funnelling effect of the Cadiz Channel would amplify the velocity significantly while maintaining a semidiurnal periodicity.

(2) Internal tides and waves. Where the barotropic tidal current interacts with bathymetric gradients and a stratified water column it can generate baroclinic oscillations of significant magnitude. These are characterised by vertical oscillations of isopycnic surfaces and by very variable velocities in the vertical scale. These perturbations are commonly produced on the continental slope, where barotropic tidal currents are more intense than in the open ocean, especially where there are abrupt slope changes. They are also known as internal tides. These tides are able to rapidly propagate their energy towards the deep ocean producing still higher current intensities (Pingree and New, 1989; Shanmugan, 2012, 2013), in particular where the currents induced by the internal tide feel the canalising effects of bottom topography. These also maintain a semidiurnal periodicity. They have recently been implicated in shaping the northwestern slope of the Alboran Sea (Puig et al., 2004) and continental slopes more generally (Cacchione et al., 2002; Hernández-Molina et al., 2011; Pomar et al., 2012; Shanmugan, 2013).

(3) Meteorologically-induced internal waves. Sudden changes in atmospheric pressure and winds can force barotropic edge waves over the continental shelf, which in turn interact with the stratified waters over the continental slopes where they are able to generate a different suite of internal waves (Baringer and Price, 1999; Bruno et al., 2006; Shanmugan, 2013). These waves may show shorter periods $\left(1^{\prime}-\right.$ several hours) than the basic tidal ones and even greater current velocities (maximum $=200 \mathrm{~cm} / \mathrm{s}$ and maximum vertical vel. $=20 \mathrm{~cm} / \mathrm{s})$ and density oscillation amplitudes $(\lambda=1 \mathrm{~m}$ to $>10 \mathrm{~km}$; $\mathrm{H}=$ several $\mathrm{cm}$ until $>100 \mathrm{~m}$ ) than internal tides (or tide-generated internal waves) (Shanmugan, 2012, 2013). In the Portimao Canyon area of the Gulf of Cadiz, they were seen to give current intensities approximately three times higher than those attributed to internal tides (Bruno et al., 2006).

(4) Other factors. Benthic storm events are well known from bottom current systems in other parts of the world (Hollister et al., 1980; Hollister and McCave, 1984; Nowell and Hollister, 1985; Hollister, 1993), leading to flow velocities that are enhanced by an order of magnitude. These events occur with variable periodicity of the order of a few months, but have not yet been reported from the Gulf of Cadiz region. Natural flow instabilities of shorter and variable periods are the norm in bottom currents related to the original surging nature of water exchange through the Gibraltar gateway (Bryden et al., 1994) and thence to flow interaction with local topography. In fact, Melières et al. (1970) proposed small-scale flow turbulence of this sort to explain patterns of small ripples superimposed on sand dunes in the Gulf of Cadiz.

\subsection{Towards an explanation}

From the above considerations, there is little doubt that the flow regime through the Cadiz Channel is likely to be highly dynamic, with a variability between shorter and longer timescales. We suggest that the data presented in this paper provide a convincing demonstration of current variability with a distinct semidiurnal tidal periodicity. Evidence from the Cadiz Channel and its associated secondary channel clearly shows current vane orientation responding to an up-channel, flood tidal current at a time close to the spring tide maximum, and relatively little current movement in any preferred sense during the slack low tidal period. Furthermore, some photographs show clouds of suspended sediment, presumably due to the bottom photographic assembly hitting the seafloor, moving up-channel with the flood tide. Others show interference ripples in which the weaker secondary ripple set may have been caused by tidal currents, but the evidence for this remains equivocal. Several previous studies have also proposed the importance of tidal forcing in the deepwater Gulf of Cadiz (Boyum, 1967; Jimenez, 2002), while Lobo et al. (2000) have noted very strong tidal currents creating sand waves on the continental shelf close to the Straits of Gibraltar.

However, there is no doubt that the dominant and strongest current influence, as evidenced by almost all bedforms observed in the photographs, is that of the down-channel directed MOW bottom current. Maximum current velocities, leading to the development of sand waves and gravel stringers, seem likely to be achieved by a combination of barotropic tides and internal tides that reinforce the normal MOW flow. In addition, the data presented does not rule out the likely additional effects of meteorologically-induced internal waves over the continental slope which may exert an even greater influence on current intensity than those induced by tides (barotropic and internal tides), when they occur. The more normal current velocities, and 
generation of the range of ripple types most common on the channel floor, are due to normal MOW flow interacting with normal tidal conditions. In all cases the canalising effect of the Cadiz Channel will amplify tidal influence.

\subsection{Seasonal to glacial/interglacial variation of MOW}

There are also other longer-term variations of the MOW that will affect sedimentation in the Cadiz Channel. Ambar et al. (1999) demonstrated a clear seasonal variability in MOW behaviour. They reported an enhanced flow of the Lower MOW during winter time, whereas the Upper MOW is more active during summer time. At a still longer time scale, an enhanced MOW circulation has been postulated during cold periods (Heinrich events, Glacial stages) in comparison to warmer periods (Llave et al., 2006; Voelker et al., 2006; Toucanne et al., 2007). Schönfeld and Zahn (2000) reported that during glacial periods an enhanced MOW sank to a depth of around $700 \mathrm{~m}$ deeper than today along the Atlantic Iberian margin, i.e. to around $1600-2200 \mathrm{~m}$ water depth. However, data presented by Llave et al. (2006) indicate a more complicated response, with a strengthening of the Lower MOW core during climatic cooling and a stronger Upper MOW core circulation during warm intervals.

In this context, the temporal and spatial occurrence of sandy contourites was controlled by variations in bathymetric position and current strength of the MOW. A deep and vigorous lower core of MOW would result in a stronger interaction with the seafloor at greater depths, favouring more activity in the deeper contourite channels, involving significant erosive processes and greater development of sandy contourites in the central area of the middle slope. We should expect, therefore, greater bottom current activity, enhanced by internal tides and internal waves along the Cadiz Contourite Channel, during winter and also during cold periods.

\subsection{Contourite sands: target for future research}

The sand-dominated contourite facies actively forming in the Cadiz Contourite Channel and the Cadiz Sand Sheet are comparable with those from other continental margins, such as those off Brazil and north-eastern UK (Viana et al., 1998; Stow et al., 2002b,c; Akhmetzhanov et al., 2007). The potential that these could become a future deep-water hydrocarbon exploration target has been noted by Viana et al. (2007), Viana (2008, 2010), Stow et al. (2011a, 2011b) and Brackenridge et al. (2013), with recognition that they most commonly form in one of two environments. Firstly, as laterally extensive sandy sheeted drifts, and secondly, as in the case of this study area, as channel-floor cover or patch drifts in contourite channels. Preliminary analyses of these different contourite sands indicate good potential hydrocarbon reservoir properties. Vigorous bottom water currents, such as those demonstrated in the Cadiz Contourite Channel, deposit and winnow sand and gravel sediment, whereas finer grain sizes are removed and transported down-current. The result of this winnowing is a well-sorted clean sand deposit (Nelson et al., 1993). Sheeted drifts can reach several $100 \mathrm{~m}$ in thickness, and on burial are predicted to maintain good porosity and permeability (Brackenridge et al., 2013).

These sand-rich contourites have been positively identified in the subsurface in only a very few cases (Mutti et al., 1980; Moraes et al., 2007; Shanmugam, 2012; Brackenridge et al., 2013). This is in part due to poor understanding of both the nature and preservation of defining features. The lack of distinguishing features, especially for muddy sands, has been attributed to intense bioturbation at the time of deposition and the consequent destruction of features that could be used to discriminate contourites from other deep-water facies such as turbidites (Stow and Faugères, 2008). However, work on cleaner sand-rich contourite deposits is still very much in its infancy and a robust set of diagnostic criteria have yet to be developed. Natural laboratories such as the Gulf of Cadiz provide ideal conditions for evaluation of these deposits and provide a good quality end-member example of a sandy contourite depositional system, including sheeted and channel drifts, and ancient and modern examples. Work on the Cadiz channel to determine channel evolution and fill facies will aid future identification of these potential reservoirs in the subsurface. Just as turbidite channels can be mapped using seismic attributes, contourite channels may be identifiable in acoustic data. This has been done in the Santos Basin Miocene section where high amplitude acoustic facies have been used to pick out the Santos Channel (Duarte and Viana, 2007). Further understanding of their channel fill facies and any differences from turbidite systems is much needed.

\section{Conclusion}

In this paper, we have detailed the development and characteristics of a contourite channel, which is as long, wide and deep as many turbidity current channels, but which has been cut and shaped by bottom currents, and by their interaction with a bottom topography influenced by neotectonics. In places it is floored by contourite sands and gravel.

Until recently, most sandy contourites have been considered as thin and muddy sand intercalations within dominant mud-rich contourite drifts. This paper contributes to the better understanding of clean sandy contourites, forming as extensive sand sheets and on the floors of contourite channels. They form large-scale sand waves and dunes, often covered by trains of smaller bedforms. These features better preserve their internal primary sedimentary structures (parallel and cross-lamination), compared with the thin sandy contourites in muddy drifts where all traces of primary structures have been obliterated by intense bioturbation.

The range of bedforms observed in the Cadiz Channel indicates their deposition by strong bottom currents, as well as a marked temporal variability of current velocity. We present strong evidence that these deposits have been affected by the dynamic interaction of MOW flow with currents showing primarily semidiurnal tidal periodicity. These are most likely a combination of barotropic and internal tides. At times these are further augmented by meteorologically-induced internal waves over the continental slope, of shorter period than internal tides, which can exert an even greater influence on current intensity.

To our knowledge, there have been no previous direct observations reported in the literature of the effects of internal tides and internal waves in contourite channel systems. Indeed, these data will also contribute to the ongoing debate surrounding the recognition of internal-wave and internal-tide deposits in ancient sedimentary successions (Gao et al., 1998; He et al., 2011; Shanmugam et al., 2011; Shanmugam, 2012, 2013). Further documentation of shortand medium-term variability in the MOW bottom current system remains a key objective for future work.

\section{Acknowledgements}

DAV Stow acknowledges receipt of a 'Mobility Award' from the Spanish Ministry of Education and Science (ref: SAB2005-0182) during which time he was working at the Instituto Español de Oceanografia (IEO, Malaga) during 2006. This work has been also carried out during research stages of FJ Hernández-Molina at National Oceanographic Centre of Southampton, NOCS (UK) at 2007 funded by the Secretaría de Estado de Educación y Universidades (PR2006-0275) and at Heriot Watt University during 2009-2010 (PR2009-0343) and during the sabbatical year 2013. Thanks are due to the captain and crew of R/V Cornide de Saavedra (IEO). The Spanish “Comisión Interministerial de Ciencia y Tecnología" supports this research through the Projects MAR-98-0209 (TASYO); CTM 2008-06399-C04/MAR (CONTOURIBER) and CTM201239599-C03-01 (MOWER). R Brackenridge is supported by an EPSRC DTA PhD scholarship. The authors would like to thank Dr. V. Hanquiez 
(Univ. Bordeaux, France) for sending us his original figure with good resolution used here as the Fig. 3B. Photographic operations were carried out by Francisco Gonzalez. Initial interpretation of the photographic evidence was by Jo Rolf at Southampton University. Finally, we also thank David Van Rooij, Thierry Mulder, one anonymous reviewer and David Piper for their interest and suggestions, which have helped us to improve the final version of our manuscript.

\section{References}

Akhmetzhanov, A., Kenyon, N.H., Habgood, E., Van Der Mollen, A.S., Neilsen, T., Ivanov, M., Shashkin, P. 2007. North Atlantic contourite sand channels. In: Viana, A.R., Rebesco, M. (Eds.), Economic and Palaeoceanographic Significance of Contourite Deposits. Special Publications, 276. Geological Society of London, pp. 81-94.

Ambar, I., Howe, M.R., 1979. Observations of the Mediterranean Outflow I. Mixing in the Mediterranean Outflow. Deep-Sea Research 26A, 535-554.

Ambar, I., Armi, L., Bower, A., Ferreira, T., 1999. Some aspects of time variability of the Mediterranean water off south Portugal. Deep-Sea Research I 46, 1109-1136.

Baraza, J., Ercilla, G., Nelson, C.H., 1999. Potential geologic hazards on the eastern Gulf of Cadiz slope (SW Spain). Marine Geology 155, 191-215.

Baringer, M.O., Price, J.F., 1997. Momentum and energy balance of the Mediterranean outflow. Journal of Physical Oceanography 27 (8), 1678-1692.

Baringer, M.O., Price, J.F., 1999. A review of the physical oceanography of the Mediterranean Outflow. Marine Geology 155, 63-82.

Boyum, G., 1967. Hydrological observations of the M/S "Helland-Hansen" and current measurements in the area west of Gibraltar. NATO Sub-Committee on Oceanographic Research Technical Reports 34, 35-36.

Brackenridge, R.A., Hernández-Molina, F.J., Stow, D.A.V., Llave, R., 2013. A Pliocene mixed contourite-turbidite system offshore the Algarve Margin, Gulf of Cadiz: Seismic response, margin evolution and reservoir implications. Marine and Petroleum Geology 46, 36-50. http://dx.doi.org/10.1016/j.marpetgeo.2013.05.015.

Bruno, M., Vázquez, A., Gómez-Enri, J., Vargas, J.M., García-Lafuente, J.M., RuizCañavate, A. Mariscal, L. Vidal, J.M., 2006. Observations of internal waves and associated mixing phenomena in the Portimao Canyon area. Deep Sea Research Part II: Topical Studies in Oceanography 53 (11-13), 1219-1240.

Bryden, H.L., Candela, J., Kinder, T.H., 1994. Exchange through the Strait of Gibraltar. Progress in Oceanography 33, 201-248.

Cacchione, D.A., Pratson, L.F., Ogston, A.S., 2002. The shaping of continental slopes by internal tides. Science 269, 724-727.

Criado-Aldeanueva, F., García-Lafuente, J., Vargas, J.M., Del Río, J., Vázquez, A., Reul, A Sánchez, A., 2006. Distribution and circulation of water masses in the Gulf of Cadiz from in situ observations. Deep Sea Research, Part II 53, 1144-1160.

Díaz del Río, V., Somoza, L., Martínez-Frías, J., Mata, M.P., Delgado, A., HernándezMolina, F.J., Lunar, R., Martín-Rubí, J.A., Maestro, A., Fernández-Puga, M.C., León, R., Llave, E., Medialdea, T., Vázquez, J.T., 2003. Vast fields of hydrocarbon-derived carbonate chimneys related to the accretionary wedge/olistostrome of the Gulf of Cadiz. Marine Geology 195, 177-200.

Duarte, C.S.L., Viana, A.R., 2007. Santos Drift Systm: stratigraphic organization and implications for late Cenozoic palaeocirculation in the Santos Basin, SW Atlantic Ocean. In: Viana, A.R., Rebesco, M. (Eds.), Economic and Palaeoceanographic Significance of Contourite Deposits. Special Publications, 276. Geological Society of London, pp. 171-198

Faugères, J.C., Frappa, M., Gonthier, E., De Resseguier, A., Stow, D.A.V., 1985. Modelé et facies de type contourite a la surface d'une ride sédimentaire édifiée par des courants issus de la veine d'eau méditerranéenne (ride du Faro, Golle de Cadix). Bulletin de la Societe Geologique de France I (1), 35-47.

Fernández-Puga, M.C., Váquez, JT., Somoza, L., Díaz del Ríoa, V., Medialdea, T., Mata M.P., León, R., 2007. Gas-related morphologies and diapirism in the Gulf of Cadiz. GeoMarine Letters. http://dx.doi.org/10.1007/s00367-007-0076-0.

Gao, Z.Z., Eriksson, K.A., He, Y.B., Luo, S.S., Guo, J.H., 1998. Deep-water Tractive Current Deposits - The study of Internal-tide, Internal-wave and Contour Current Deposits. Science Press, Beijing, New York (128 pp.).

García, M., 2002. Caracterización morfológica del sistema de canales y valles submarinos del talud medio del Golfo de Cádiz (SO de la Península Ibérica): Implicaciones oceanográficas. (Tesis de Licenciatura) Facultad de Ciencias del Mar, Univ. Cádiz (114 pp.).

García, M., Hernández-Molina, F.J., Llave, E., Stow, D.A.V., León, R., Fernández-Puga, M.C. Díaz del Río, V., Somoza, L., 2009. Contourite erosive features caused by the Mediterranean Outflow Water in the Gulf of Cádiz: Quaternary tectonic and oceanographic implications. Marine Geology 257 (1-4), 24-40. http://dx.doi.org/10.1016/ j.margeo.2008.10.009.

Gonthier, E.G., Faugères, J.C., Stow, D.A.V., 1984. Contourite facies of the Faro Drift, Gulf of Cadiz. In: Stow, D.A.V., Piper, D.J.W. (Eds.), Fine-Grained Sediments: Deep-Water Processes and Facies. 15. Geological Society Special Publication, pp. 775-797.

González, F.J., Somoza, L., Lunar, R., Martínez-Frías, J., Martín Rubí, J.A., Torres, T., Ortiz, J.E., Díaz del Río, V., 2007. Fe-Mn nodules associated with hydrocarbon seeps: a new discovery in the Gulf of Cadiz (eastern central Atlantic). Episodes 30 (3), 187-196.

González, FJ., Somoza, L., Lunar, R., Martínez-Frías, J., Martín Rubí, J.A., Torres, T., Ortiz, J.E. Díaz del Río, V., Pinheiro, L., Magalhaes, V.H., 2009. Hydrocarbon-derived ferromanganese nodules in carbonate-mud mounds from the Gulf of Cadiz: mud-breccia sediments and clasts as nucleation sites. Marine Geology 261 (1/4), 64-81.
González, F.J., Somoza, L., Lunar, R., Martínez-Frías, J., Martín Rubí, J.A., Torres, T., Ortiz, J.E., Díaz del Río, V., 2010. Internal features, mineralogy and geochemistry of Fe-Mn nodules from the Gulf of Cadiz: the role of the Mediterranean outflow water undercurrent. Journal of Marine Systems 80 (3/4), 203-218. http://dx.doi.org/10.1016/ j.jmarsys.2009.10.010.

Gràcia, E., Dañobeitia, J., Vergés, J., Bartolomé, R., Córdoba, D., 2003. Crustal architecture and tectonic evolution of the Gulf of Cádiz (SW Iberian margin) at the convergence of the Eurasian and African plates. Tectonics 22 (4), 1033-1051. http://dx.doi.org/ 10.1029/2001TC901045.

Habgood, E.L., 2002. Alongslope and Downslope Sediment Transport Processes in the Gulf of Cadiz. Thesis, Univ, Southampton (237 pp.).

Habgood, E.L., Kenyon, N.H., Masson, D.G., Akhmetzhanov, A., Weaver, P.P.E., Gardner, J., Mulder, T., 2003. Deep-water sediment wave fields, bottom current sand channels and gravity flow channel-lobe system: Gulf of Cadiz, NE Atlantic. Sedimentology $50,483-510$.

Hanquiez, V., 2006. Processus sédimentaires et activité de la Veine d'Eau Méditerranéene au cours du Quaternaire terminal dans le Golfe de Cádiz. (PhD thesis) University of Bordeaux-I (358 pp.).

Hanquiez, V., Mulder, T., Lecroart, P., Gonthier, E., Marchès, E., Voisset, M., 2007. High resolution seafloor images in the Gulf of Cadiz, Iberian margin. Marine Geology 246, 42-59.

He, Y.-B., Luo, J.-X., Li, X.-D., Gao, Z.-Z., Wen, Z., 2011. Evidence of internal-wave and internal-tide deposits in the Xujiajuan Formation of the Xiangshan Group, Ningxia, China. Geo-Marine Letters. http://dx.doi.org/10.1007/s00367-011-0253-z.

Hernández-Molina, F.J., Llave, E., Somoza, L., Fernández-Puga, M.C., Maestro, A., León, R., Barnolas, A., Medialdea, T., García, M., Vázquez, J.T., Díaz del Río, V., FernándezSalas, L.M., Lobo, F., Alveirinho Dias, J.M., Rodero, J., Gardner, J., 2003. Looking for clues to paleoceanographic imprints: a diagnosis of the gulf of Cadiz contourite depositional systems. Geology 31 (1), 19-22.

Hernández-Molina, FJ. Llave, E. Stow, D. García, Somoza, L, Vázquez, JT, Lobo, F, Maestro, A., Díaz del Río, V., León, R., Medialdea, T., Gardner, J., 2006. The Contourite Depositional System of the Gulf of Cadiz: a sedimentary model related to the bottom current activity of the Mediterranean Outflow Water and its interaction with the continental margin. Deep Sea Research II 53, 1420-1463.

Hernández-Molina, F.J., Serra, N., Stow, D.A.V., Ercilla, G., Llave, E., Van Rooij, D., 2011. Along-slope oceanographic processes and sedimentary products around Iberia. Geo-Marine Letters 31 (5/6). http://dx.doi.org/10.1007/s00367-011-0242-2.

Hollister, C.D., 1993. The concept of deep-sea contourites. Sedimentary Geology 82, $5-11$.

Hollister, C.D., McCave, N., 1984. Sedimentation under benthic storms. Nature 309 (5,965), 220-225.

Hollister, C.D., Nowell, A.R.M., Smith, J.D., 1980. The third annual report of the high energy boundary layer experiment. WHOI Technical Report 80, 32-48.

Jané G, 2007. Distribución espacial de las chimeneas carbonatadas en el Golfo de Cádiz y su relación con los procesos tectónicos y oceanográficos. (Disertation) Instituto Geológico y Minero de España and Universidad Complutense de Madrid (126 pp.).

Jiménez, M.L., 2002. Estudio de las distribuciones pico-nanoplanctónicas y su acoplamiento a fenómenos físicos en el Cañón Submarino de Portimao y áreas adyacentes mediante citometría de flujo. (Disertation) Universidad de Málaga (92 pp.).

Kenyon, N.H., Belderson, R.H., 1973. Bedforms of the Mediterranean undercurrent observed with side-scan sonar. Sedimentary Geology 9, 77-99.

León, R., Somoza, L., Medialdea, T., Hernández-Molina, F.J., Vázquez, J.T., Díaz-del-Rio, V., Gonzalez, F.J., 2010. Pockmarks, collapses and blind valleys in the Gulf of Cadiz. Geo-Marine Letters 30, 231-247. http://dx.doi.org/10.1007/s00367-0090169-z.

Llave, E., 2003. Análisis morfosedimentario y estratigráfico de los depósitos contorníticos del Golfo de Cádiz: Implicaciones paleoceanográficas. (Tesis Doctoral) Facultad de Ciencias del Mar, Universidad de Cádiz (343 pp.).

Llave, E., Hernández-Molina, F.J., Somoza, L., Díaz-del-Río, V., Stow, D.A.V., Maestro, A., Alveirinho Dias, J.M., 2001. Seismic stacking pattern of the Faro-Albufeira contourite system (Gulf of Cadiz): a Quaternary record of paleoceanographic and tectonic influences. Marine Geophysical Research 22, 487-508.

Llave, E., Flores, A., Hernández-Molina, F.J., Sierro, P., Somoza, L., Díaz del Río, V., Martínez del Olmo, W., 2004. Cronoestratigráfia de los depósitos cuaternarios del talud continental del Golfo de Cádiz a partir del análisis de nanofósiles calcáreos. Geo-Temas 6 (5), 183

Llave, E., Schönfeld, J., Hernández-Molina, F.J., Mulder, T., Somoza, L., Diaz del Río, V., 2006. High-resolution stratigraphy of the Mediterranean outflow Contourite System in the Gulf of Cadiz during the Late Pleistocene: the impact of Heinrich events. Marine Geology 227 (3-4), 241-262.

Llave, E. Hernández-Molina, F.J., Somoza, L. Stow, D., Díaz del Río, V. 2007a. Quaternary evolution of the Contourite Depositional System in the Gulf of Cadiz. In: Viana, A. Rebesco, M. (Eds.), Economic and Paleoceanographic Importance of Contourites. Special Publication, 276. Geological Society of London, pp. 49-79.

Llave, E., Hernández-Molina, F.J., Stow, D., Fernández-Puga, M.C., García, M., Vázquez, J.T., Maestro, A., Somoza, L., Díaz del Río, V., 2007b. Reconstructions of the Mediterranean Outflow Water during the Quaternary since the study of changes in buried mounded drift stacking pattern in the Gulf of Cadiz. Marine Geophysical Research 28, 379-394. http://dx.doi.org/10.1007/s11001-007-9040-7.

Llave, E., Matias, H., Hernández-Molina, F.J., Ercilla, G., Stow, D.A.V., Medialdea, T., 2011. Pliocene-Quaternary contourites along the northern Gulf of Cadiz margin: sedimentary stacking pattern and regional distribution. Geo-Marine Letters 31 (5/6). http://dx.doi.org/10.1007/s00367-011-0241-3.

Lobo, F.J., Hernández-Molina, F.J., Somoza, L., Rodero, J., Maldonado, A., Barnolas, A., 2000. Patterns of bottom current flow deduced from dune asymmetries over the Gulf of Cadiz shelf (southwestern Spain). Marine Geology 164, 91-117. 
Madelain, F., 1970. Influence de la topographie du fond sur l'ecoulement méditerranéen entre le Detroit de Gibraltar et le Cap Saint-Vincent. Cahiers Oceanographiques 22, 43-61.

Maestro, A., Jané, G., García-Mayordomo, J., Fernández-Revuelta, B., Rodríguez-Pascua, M.A., Marínez-Díaz, J.J., Pérez-López, R., 2011. Cause of the rupture and distribution of broken submarine carbonate chimneys in the Gulf of Cadiz (southwestern Spain). Quaternary International 242 (1), 240-253.

Maldonado, A., Somoza, L., Pallarés, L., 1999. The Betic orogen and the Iberian-African boundary in the Gulf of Cadiz: geological evolution (central North Atlantic). Marine Geology 155, 9-43.

Martín-Puertas, C., Mata, M.P., Fernández-Puga, M.C., Díaz del Río, V., Vázquez, J.T. Somoza, L., 2007. A comparative mineralogical study of gas-related sediments of the Gulf of Cadiz. Geo-Marine Letters 27 (2-4), 223-235.

Melières, F., 1974. Recherches sur la dynamique sédimentuire du Golfe de Cadiz (Espagne). (These de Doctoral) Univ. Paris A (235 pp.).

Melières, F., Nesteroff, W.D., Lancelot, Y., 1970. Etude photographique des fonds du Golfe de Cádiz. Cahiers Oceanographiques 22, 63-72.

Merinero, R., Lunar, R., Martínez-Frías, J., Somoza, L., Díaz-del-Río, V., 2008. Iron oxide and sulphide mineralization in hydrocarbon seep-related carbonate submarine chimneys, Gulf of Cadiz (SW Iberian Peninsula). Marine and Petroleum Geology 25, 706-713.

Moraes, M.A.S., Maciel, W.B., Braga, M.S.S., Viana, A.R., 2007. Bottom-current reworked Palaeocene-Eocene deep-water reservoirs of the Campos Basin, Brazil. In: Viana, A.R., Rebesco, M. (Eds.), Economic and Palaeoceanographic Significance of Contourite Deposits. Special Publications, 276. Geological Society of London, pp. 25-47.

Mulder, T., Lecroart, P., Voisset, M., Le Drezen, E., Gonthier, E., Hanquiez, V., Faugères, J.-C., Gervais, A., Kenyon, N.H., Schönfeld, J., Hernández-Molina, F.J., Habgood, E., Poirier, D., Llave-Barranco, E., Estrada, F., Volker, A., Gorini, C., Freitas, P., Lobo Sanchez, F., Fuchey, Y., Fernandez, L.M., Morel, J., 2002. Past deep-ocean circulation and the palaeoclimate record-Gulf of Cadiz. EOS, Transations, American Geophysical Union 83 (43), 481-488.

Mulder, T., Voisset, M., Lecroart, P., Le Drezen, E., Gonthier, E., Hanquiez, V., Faugères, J.-C., Habgood, E., Hernández-Molina, F.J., Estrada, F., Llave, E., Poirier, D., Gorini, C., Fuchey, Y., Volker, A., Freitas, P., Lobo Sanchez, F., Fernandez, L.M., Morel, J., 2003. The Gulf of Cadiz: an unstable giant contouritic levee. Geo-Marine Letters 23 (1), 7-18.

Mulder, T., Lecroart, P., Hanquiez, V., Marches, E., Gonthier, E., Guedes, J.C., Thiébot, E., Jaaidi, B., Kenyon, N., Voisset, M., Perez, C., Sayago, M., Fuchey, Y., Bujan, S., 2006. The western part of the Gulf of Cadiz: contour current sand turbidity currents interactions. Geo-Marine Letters 26, 31-41.

Mutti, E., Barros, M., Possato, S., Rumenos, L., 1980. Deepsea fan turbidite sediments winnowed by bottom currents in the Eocene of the Campos Basin, Brazilian offshore. International Association of Sedimentologists, First European Regional Meeting, Abstracts, p. 114.

Nelson, C.H., Baraza, J., Maldonado, A., 1993. Mediterranean undercurrent sandy contourites, Gulf of Cadiz, Spain. Sedimentary Geology 82, 103-131.

Nelson, C.H., Baraza, J., Maldonado, A., Rodero, J., Escutia, C., Barber, J.H., 1999. Influence of the Atlantic inflow and Mediterranean outflow currents on Late Quaternary sedimentary facies of the Gulf of Cadiz continental margin. Marine Geology 155, 99-129.

Nowell, A.R.M., Hollister, C.D., 1985. The objetives and rationate of HEBBLE. In: Nowell, A.R.M., Hollister, C.D. (Eds.), Deep Ocean Sediment Transport - Preliminary Results of the High Energy Benthic Boundary Layer ExperimentMarine Geology 66, $1-11$.

Pingree, R.D., New, A.L., 1989. Downward propagation of internal tidal energy in the Bay of Biscay. Deep-Sea Research 36, 735-758.

Pomar, L., Morsilli, M., Hallock, P., Bádenas, B., 2012. Internal waves, an under-explored source of turbulence events in the sedimentary record. Earth-Science Reviews 111, 56-81.

Puig, P., Palanques, A., Guillén, J., El Khatab, M., 2004. Role of internal waves in the generation of nepheloid layers on the northwestern Alboran slope: implications for continental margin shaping. Journal of Geophysical Research 109, C09011. http://dx.doi.org/10.1029/2004JC002394.

Roque, C., Duarte, H., Terrinha, P., Valadares, V., Noiva, J., Cachao, M., Ferreira, J. Legoinha, P., Zitellini, N., 2012. Pliocene and Quaternary depositional model of the Algarve margin contourite drifts (Gulf of Cadiz, SW Iberia): seismic architecture, tectonic control and palaeoceanographic insights. Marine Geology 303, 42-62.

Schönfeld, J., Zahn, R., 2000. Late Glacial to Holocene history of the Mediterranean Outflow. Evidence from benthic foraminiferal assemblages and stable isotopes at the Portuguese margin. Palaeogeography, Palaeoclimatology, Palaeoecology $159,85-111$.

Shanmugam, G., 2012. New perspectives on deep-water sandstones: origin, recognition, initiation and reservoir quality. Handbook of Petroleum Exploration and Production. 9. Elsevier, Amsterdam 524.
Shanmugam, G., 2013. Modern internal waves and internal tides along oceanic pycnoclines: challenges and implications for ancient deep-marine baroclinic sands. AAPG Bulletin 97 (5), 767-811.

Shanmugam, G., Discussion of He, et al., 2011. (2011, Geo-Marine Letters) Evidence of internal wave and internal-tide deposits in the Middle Ordovicia Xujiajuan Formation of the Xiangshan Group, Ningxia, China. Geo-Marine Letters. http:// dx.doi.org/10.1007/s00367-011-0264-9.

Somoza, L., Díaz del Río, V., Leon, R., Ivanov, M.K., Fernández-Puga, M.C., Gardner, J. Hernández-Molina, F.J., Pinheiro, L.M., Rodero, J., Lobato, A., Maestro, A., Vázquez, J.T., Medialdea, T., Fernandez-Salas, L.M., 2003. Seabed morphology and hydrocarbon seepage in the Gulf of Cadiz mud volcano area: acoustic imagery, multibeam and ultra-high resolution seismic data. Marine Geology 195, 153-176.

Stow, D.A.V., Faugères, J.C., 2008. Contourite facies and the facies model. In: Rebesco, M., Camerlenghi, A. (Eds.), Contourites, Developments in Sedimentology. 60 Elsevier pp. 223-256.

Stow, D.A.V., Faugères, J.C., Gonthier, E., 1986. Facies distribution and textural variations in Faro drifts contourites: velocity fluctuation and drift growth. Marine Geology 72, 71-100.

Stow, D.A.V., Faugères, J.C., Gonthier, E., Cremer, M., Llave, E., Hernández-Molina, F.J. Somoza, L., Díaz del Río, V., 2002a. Faro-Albufeira drift complex, Northern Gulf of Cadiz. In: Stow, D.A.V., Pudsey, C.J., Howe, J., Faugères, J.C. (Eds.), IGCP 432. DeepWater Contourite Systems: Modern Drifts and Ancient Series, Seismic and Sedimentary Characteristics. Special Publication, 22. Geological Society of London, pp. 137-154.

Stow, D.A.V., Faugères, J.C., Howe, J.A., Pudsey, C.J., Viana, A.R., 2002b. Bottom currents, contourites and deep-sea sediment drifts: current state-of-the-art. In: Stow, D.A.V., Pudsey, C.J., Howe, J.A., Faugères, J.C., Viana, A.R. (Eds.), Deep-Water Contourite Systems: Modern Drifts and Ancient Series, Seismic and Sedimentary Characteristics. Memoir, 22. Geological Society of London, pp. 7-20.

Stow, D.A.V., Armishaw, J.E., Holmes, R., 2002c. Holocene contourite sand sheet on the Barra Fan slope, NW Hebridean margin. In: Stow, D.A.V., Pudsey, C.J., Howe, J.A., Faugères, J.-C., Viana, A.R. (Eds.), Deep-water Contourite Systems: Modern Drifts and Ancient Series, Seismic and Sedimentary Characteristics. 22. Geological Society of London Memoir, pp. 99-120.

Stow, D.A.V., Hernández-Molina, F.J., Llave, E., Sayago, M., Díaz del Río, V., Branson, A. 2009. Bedform-velocity matrix: the estimation of bottom current velocity from bedform observations. Geology 37 (4), 327-330.

Stow, D.A.V., Hernández-Molina, F.J., Hodell, D., Alvarez-Zarikian, C.A., 2011a. Integrated Ocean Drilling Program Expedition 339 Scientific Prospectus Mediterranean Outflow Environmental significance of the Mediterranean Outflow Water and its global implications. Integrated Ocean Drilling Program. Scientific Prospectus 339. http:// dx.doi.org/10.2204/iodp.sp.339.2011 (68 pp.).

Stow, D.A.V., Brackenridge, R., Hernandez-Molina, F.J., 2011b. Contourite sheet sands: new deepwater exploration target. Abstract American Association of Petroleum Geologists Annual Conference, Houston 2011.

Thorpe, S.A., 1976. Variability of the Mediterranean in the Gulf of Cadiz. Deep-Sea Research 23, 711-727.

Toucanne, S., Mulder, T., Schoenfeld, J., Hanquiez, V., Gonthier, E., Duprat, J., Cremer, M., Zaragosi, S., 2007. Contourites of the Gulf of Cadiz: a high-resolution record of the paleocirculation of the Mediterranean outflow water during the last 50,000 years. Palaeogeography Palaeoclimatology Palaeoecology 246, 354-366.

Viana, A., 2008. Economic relevance of contourites. In: Rebesco, M., Camerlenghi, A. (Eds.), Contourites. Developments in Sedimentology, vol 60. Elsevier, Amsterdam, pp. 493-510.

Viana, A., 2010. The economic importance of contourites. Geo-Temas 11, 181-182.

Viana, A.R., Faugères, J.-C., Stow, D.A.V., 1998. Bottom-current-controlled sand deposits a review of modern shallow- to deep-water environments. Sedimentary Geology 115 53-80.

Viana, A.R., Almeida Jr., W., Nunes, M.C.V., Bulhões, E.M., 2007. The economic importance of contourites. In: Viana, A.R., Rebesco, M. (Eds.), Economic and Palaeoceanographic Significance of Contourite Deposits. Special Publications, 276. Geological Society of London, pp. 1-23.

Voelker, A., Lebreiro, S., Schönfeld, J., Cacho, I., Exlenkenser, H., Abrantes, F., 2006. Mediterranean outflow strengthenings during Northern Hemisphere coolings: a salt sources for the glacial Atlantic? Earth and Planetary Science Letters 245, 39-55.

Weaver, P.P.E., Wynn, R.B., Kenyon, N.H., Evans, J., 2000. Continental margin sedimentation, with special reference to north-east Atlantic margin. Sedimentology 47, 239-256.

Zenk, W., 1975. On the Mediterranean outflow west of Gibraltar. Meteor Forscir Ergebuisse A (16), 23-34.

Zenk, W., Armi, L., 1990. The complex spreading patterns of Mediterranean water off the Portuguese continental slope. Deep-Sea Research 37, 1805-1823.

Zitellini, N., Gràcia, E., Matias, L., Terrinha, P., Abreu, M.A., DeAlteriis, G., Henriet, J.P. Dañobeitia, J.J., Masson, D.G., Mulder, T., Ramella, R., Somoza, L., Diez, S., 2009 The quest for the Africa-Eurasia plate boundary west of the Strait of Gibraltar Earth and Planetary Science Letters 280 (1-4), 13-50. http://dx.doi.org/10.1016/ j.epsl.2008.12.005. 